\title{
Âdem-i Merkeziyetçilik-Merkeziyetçilik Tartışmaları Bağlamında Osmanlı Devleti ve Fransa'da Savaşlar, Mali Baskılar, Kurumsal Değişim
}

Perihan Hazel KAYA (https://orcid.org/0000-0002-9878-4194), Selcuk University, Turkey; perihaner@selcuk.edu.tr

\section{Wars, Fiscal Pressures, Institutional Change in the Ottoman Empire and France in the Context of Decentralization and Centralization Debates}

\begin{abstract}
Income sources of countries have significant effects on their institutional structures. To what extent could countries that were more dependent on local taxpayers for their income sources in the early modern period develop their institutional structures? In this study, an answer to this question is sought by comparing the evolution of the Ottoman Empire and French financial institutions, which collected a significant part of their income with the tax farming system (iltizam) between the sixteenth and nineteenth centuries in the context of decentralization-centralization. Wars, the centralization of finance, and thus the emergence of central states are interrelated processes. While some types of taxation became centralized after the French Revolution in France, some remained decentralized. The Ottoman Empire took important steps to centralize the financial structure with the Tanzimat reform.
\end{abstract}

Keywords : Decentralization, France, Tax Farming System, Centralization, Ottoman Empire.

JEL Classification Codes : $\quad$ B10, E02, E32, E62.

\section{$\ddot{\mathrm{Oz}}$}

Ülkelerin gelir kaynakları, kurumsal yapıları üzerinde önemli etkilere sahiptir. Erken modern dönemde gelir kaynakları içinde yerel vergi mükelleflerine daha bağımlı olan ülkeler kurumsal yapılarını ne ölçüde geliştirebilmiştir? Bu çalışmada bu soruya, gelirlerinin önemli bir kısmını iltizam sistemi ile toplamış olan Osmanlı Devleti ve Fransız mali kurumlarının âdem-i merkeziyetçilikmerkeziyetçilik bağlamında XVI.-XIX. yüzyıllar arasındaki evrimine ilişkin karşılaştırmalar yapılarak cevap aranmaktadır. Savaşlar, maliyenin merkezileşmesi ve bu yolla merkezi devletlerin ortaya çıkış1 birbiriyle ilişkili süreçlerdir. Fransa'da Fransız Devriminden sonra vergilendirmenin bazı türleri merkezileşirken bazı türleri âdem-i merkeziyetçi yapıda kalmış buna karşılık Osmanlı Devleti'nde Tanzimat reformu ile birlikte mali yapının merkezileşmesi adına önemli adımlar atılmıştır.

Anahtar Sözcükler : Âdem-i Merkeziyetçilik, Fransa, İltizam Sistemi, Merkeziyetçilik, Osmanlı Devleti. 
Kaya, P.H. (2021), “Âdem-i Merkeziyetçilik-Merkeziyetçilik Tartışmaları Bağlamında Osmanlı

Devleti ve Fransa'da Savaşlar, Mali Baskılar, Kurumsal Değişim”, Sosyoekonomi, 29(50), 433-463.

\section{Giriş}

Ülkelerin idaresinin teşkilat ve faaliyet bakımından yürütülmesinde merkeziyetçilik ${ }^{1}$ ve âdem-i merkeziyetçilik ${ }^{2}$ olmak üzere iki sistem bulunmaktadır. Merkeziyetçilikte bütün yetkiler merkezden alınırken, âdem-i merkeziyetçilikte hükümet merkezince atanan memurlar yanında, merkezi hiyerarşiye dahil olmayan merciler vardır. Merkezi bir hükümet bürokrasisinin kurulması vergilerin toplanması adına modern bir ekonominin temel özelliklerinden biri olarak kabul edilir. Diğer bir özellik ise ekonomik büyümeyi artırıcı iyi ve gelişmiş kurumların varlığıdır. Günümüz ülkelerinin çoğu ne yazık ki bu tarz nitelikteki kurumlara sahip değildir. Burada tarihin rolü çok büyüktür ${ }^{3}$. İltizam sistemi XVI. yüzyıldan itibaren Avrupa'daki en temel vergi toplama yöntemiydi. Erken Modern Dönemde, Fransa, İngiltere, Prusya, Osmanlı Devleti ve Güneydoğu Asya'da uygulanan beş ayrı iltizam modeli bulunmakta idi. İngiltere, Fransa ve Prusya'da uygulanan iltizam modelinin üç belirgin türü olmakla beraber en sıra dışı vergi toplama yöntemi Prusya'da uygulanmaktaydı. İngiltere, dolaylı vergileri toplarken hem iltizam sistemini hem de merkezi vergi dairesini kullanırken Fransa dolaylı vergileri toplarken çoğunlukla iltizam sistemini kullanmıştı. Diğer yandan Fransa ve Prusya iltizam sistemini yaygın biçimde uygularken İngiltere XVII. yüzyılın sonlarında iltizamı terk edip, ücretli memurlardan oluşan vergi toplama bürokrasisi yaratmıştı (Buluş, 2010: 89-90). Öte yandan Osmanlı Devleti ve Fransa büyük ölçüde iltizam sistemine güvenmeye devam eden ülkeler olarak karşımıza çıkıyordu. Osmanlı Devleti ve Fransa'da uygulanan iltizam sistemlerinin ortak noktalarından biri de her iki ülkede de dolaylı vergilerin yanı sıra doğrudan vergileri toplamak için de kullanılmış olmasıyd ${ }^{4}$. Çağdaş özelleştirme kavramına benzer şekilde iltizam, Ortadoğu tarihinde çok az anlaşılan bir olguydu. Genellikle devlet gücünün kötüye kullanılması ve modern öncesi İslam devletlerinin çöküşünün kurumsal nedenleri üzerine tartışmalarla bağlantılı bir kavramdı. Modern dünyada vergilerin toplanması temel bir hükümet işlevi gibi görünebilir. Öyleyse temel bir soru ortaya çıkıyor: Vergi gelirini maksimize etmenin merkezi önemi göz önüne alındığında, neden Fransız kraliyeti özelleştirilmiş bir vergi tahsilat sistemi kullanmıştı? Diğer bir deyişle, dolaylı vergilerin toplanması için Fransız monarşisi, neden devlet tarafından yönetilen maaşlı görevliler seçmedi de vergi toplama hakkını sabit bir ücret karşılığında bir şirkete kiralamıştı? On sekizinci yüzyılın başında dolaylı vergilerin tahsiline yönelik böyle bir kira sözleşmesinin kabul edilmesi, Kral'ın temsilcilerini kontrol ve takip etmede karşılaştığı zorluklardan ve vergi gelirlerindeki eksikliklere karşı riskleri göze alamamasından kaynaklanmaktaydı. Bu çalışmada bu soruya erken modern dönemde yoğun bir şekilde iltizam sistemini uygulayan Osmanlı Devleti ve Fransa'nın özellikle savaşlardan

\footnotetext{
Centralisation, merkezcilik, merkezden yönetim.

Decentralisation, self-goverment, yerinden yönetim.

Literatürde tarihsel kurumlar ve günümüz performansları arasındaki ilişkiyi ele alan birçok çalışma bulunmaktadir. Örneğin, bkz. Acemoğlu, Johnson \& Robinson, 2002; Acemoğlu \& Robinson, 2014; Kuran, 2012; Rodrik, Subramanian \& Trebbi, 2004.

4 Ingiltere'de iltizam sistemi doğrudan vergilendirmede kullanılmamıştır. Bkz. Kiser \& Kane, 2001.
} 
Kaya, P.H. (2021), “Âdem-i Merkeziyetçilik-Merkeziyetçilik Tartışmaları Bağlamında Osmanlı Devleti ve Fransa'da Savaşlar, Mali Baskılar, Kurumsal Değişim”, Sosyoekonomi, 29(50), 433-463.

dolayı yaşanan benzer mali krizlere ve iletişim ve ulaşım teknolojisindeki yetersizliklere verdikleri farklı tepkileri karşılaştırılarak cevap aranmaktadır.

XVII. yüzyılda savaş harcamalarının ve kaybedilen savaşların yol açtığı nakit ihtiyacı bu ülkeleri daha kısa sürede daha fazla gelir elde yoluna sevk etmişti. Bunun için de daha önce iltizam sistemi aracılığıyla vergi tahsildarlarına verdikleri mülkiyet haklarını ihlal etmeye başlamışlar, iltizamlarını ellerinden alarak başkalarına daha yüksek bedellerle kiraya vermişlerdi. Tüm bu yaşananlar her iki ülkede de kurumsal başarısızlığa yol açtı. Bu süreçte Fransa'da, XIV. Louis döneminde monarşinin vergi toplama faaliyetlerinin önemli bir bölümünü, küçük bir varlıklı finansör grubun yönetimi altında birleştiren General Farms Şirketi $^{5}$ (Ferme Générale) ortaya çıktı ve krala karşı büyük kısıtlamalar getirmeyi başardı. Osmanlı Devleti'nde ise yaşanan mali krizler sonucu Fransa'daki General Farms Şirketine benzer bir koalisyon ortaya çıkmadı ve belirsiz mülkiyet hakları mali sistemde padişah ve vergi tahsildarlarının XVII. ve XVIII. yüzyılın çoğu döneminde anlaşmalara uymamalarından dolayı ${ }^{6}$ bir çöküşe yol açtı. Fransa' da, vergi tahsildarlarının sermayeyi bir araya getirme kabiliyeti, krallığa karşı inandırıcı bir tehdit oluşturacak kadar büyük bir ölçekte örgütlenmelerine izin verirken Osmanlı Devleti'nde vergi tahsildarları böyle bir örgütlenme içerisine giremedi bu nedenle de Osmanlı Devleti'nde kurumlar Fransa'dakinin aksine farklı bir yöne evrildi. Bunun en önemli nedenlerinden biri başarılı ve güvenilir kamu sektörü kurumlarının oluşmasında özel sektör kuruluşlarının önemli rol oynamasıydı. Erken modern Fransa ve Osmanlı Devleti tarihi incelendiğinde görülebileceği üzere, gerekli özel sektör kurumları yerinde olmadığı sürece kamu sektörü reformlarının başarılı olma olasılığı düşüktü (Balla \& Johnson, 2009: 810-811). XVII. yüzyılda Fransa'da General Farms gibi özel statüdeki bir şirket altında kişiler sermayelerini bir araya getirerek düşük maliyetlerle birleştirebilirken Osmanlı Devleti'nde İslami kaidelere dayanan inanç ve miras hukuku ve para vakıfların işleyiş yapısı kişilerin özel işletmelerde sermaye biriktirmesini yüksek maliyetlerle engelledi. $\mathrm{Bu}$ faktörler sonucu Osmanlı Devleti'nde vergi tahsildarları birleşerek bir kredi kaynağı oluşturamadı ve padişahın mali faaliyetlerine kısıtlamalar getiremedi.

Vergilendirme XVIII. yüzyılın sonlarında Fransa'da önemli bir sorundu. Adaletsiz ve aşırı vergilendirme Fransız Devrimi'nin kışkırtılmasına yardımcı oldu. Aşırıydı çünkü

5 General Farms şirketi, Fransız Devrimi’nden önceki eski/antik rejimin (ancien regime) bir ürünüydü. Şirket sonunda kendisini yok edecek Devrimin de temellerini atmıştır. Aslen Kraliyet borçlanmasını kolaylaştırmak için yaratılan Şirket, XVIII. yüzyılın sonunda mali reform üzerinde ciddi bir kısitlama getirdi. General Farms Şirketi'nin XVIII. yüzyıldaki tarihi, 1789 Devrimi’nden önceki mali krizin kökenini açılamaya yardımcı olmaktadır. General Farms Şirketi hakkında detaylı bilgi için bkz. Johnson, 2006.

6 Çalışmanın ilerleyen bölümlerinde daha ayrıntılı açıklanacağı üzere iltizam sisteminde sözleşme süresi üç yıl olarak belirtilmişse de özellikle savaş dönemlerinde devletin daha fazla gelir elde etmek amacıyla sözleşme süresi bitmeden ilk ihaleden daha yüksek tutar teklif eden yeni mültezimlere verdiği görülmektedir. Bu durum verginin toplandığ rê̂yâyı olumsuz yönde etkilemiştir. Mültezimin planlamış olduğu süre ile gerçekleşen süre arasında bir farklılık olması hem vergi gelirlerinde düşüse hem de vergi kaynă̆ının dolayısıyla reâyânın güçsüzleşmesine neden olmuştur. Mukataanın aşırı ölçüde sömürülmesine yol açan bu belirsizlik karşısında mültezim, her an iltizamı elinden alınabilir düşüncesiyle en kısa zamanda yatırımının karşılığını vergi kaynağından çıkartmaya çalışmıştır. Bkz. Çizakça, $1999 a$. 
Kaya, P.H. (2021), “Âdem-i Merkeziyetçilik-Merkeziyetçilik Tartışmaları Bağlamında Osmanlı

Devleti ve Fransa'da Savaşlar, Mali Baskılar, Kurumsal Değişim”, Sosyoekonomi, 29(50), 433-463.

Fransa, esas olarak savaş kışkırtıcılığı, büyüyen bürokrasisi ve yüksek harcamaları nedeniyle Avrupa'nın en çok vergi veren devletlerinden biri haline gelmişti. Verimsizdi çünkü birçok vergi, yolsuzluğu ve vergiden kaçınmayı teşvik eden bir sistem olan "iltizamcılar" olarak adlandırılan bir özel yükleniciler ağı tarafından toplanıyordu. Şaşırtıcı olmayan bir şekilde, antik rejimin dengesiz vergi rejimine ilişkin şikayetler Fransız Devrimi’nin önemli bir nedeni haline geldi. Bununla birlikte XVIII. yüzyılın sonunda Fransız kurumlarının esnekliği devrime güç kazandırdı. Osmanlı Devleti'nde ise, birbirini izleyen hükümetler, bir yüzyıldan fazla bir süre boyunca, az ya da çok kademeli reformlar gerçekleştirebildiler. Burada cevabı aranan son soru ise Fransız Devrimi ile vergi idaresinin merkezileşmesi arasında ilişki olup olmadığı ve Osmanlı Devleti'nde böyle bir devrim yaşanmazken mali anlamda merkezileşme çabalarının Tanzimat Fermanının ortaya çıkmasındaki etkinliğinin ne olduğudur? Tüm bu soruları cevaplamak için bu çalışmada Osmanlı Devleti ve Fransa'da vergi idaresinin tarihsel evriminin ayrıntılı bir değerlendirmesi tarihsel süreç içerisinde karşılaştırılmalı olarak yapılmaktadır. Bu doğrultuda ilk olarak her iki ülkede de en temel vergi toplama yöntemi olan iltizam sistemi ayrıntılı olarak ele alınmış ve savaşların iltizam sisteminde yol açtığı değişiklikler değerlendirilmiştir. Sonrasında Osmanlı Devleti ve Fransa'nın belirsiz mülkiyet haklarına verdikleri tepkilerin kurumsal değişimlerine etkisi âdem-i merkeziyetçi-merkeziyetçi yapı bağlamında değerlendirilerek çalışma sonlandırılmıştır.

\section{Osmanlı Devleti ve Fransız Vergi Sisteminin Kökenleri}

Osmanlı Devleti'nde vergiler şer'î ve örfi olarak iki başlık altında toplanırken, devletin halktan aldığı vergiler; Rüsum-1 Şer'̂̂ye (zekât, cizye, öşür vb.), Rüsum-1 Örfiye (çift, ispenç, arus, cürm-ü cinayet vb.) ve Avârız-1 Divaniye (Avârız akçesi, Nüzûl bedeli, Sürsat, İmdâd-î Seferiye, İmdâd-î Hazeriyye vb.) olmak üzere üç bölüme ayrılmaktaydı (Kaya, 2017:178-179). Vergi olarak zekât, genellikle beş başlık altında toplanmıştı. Bunlar; altın ve gümüşten, tarımsal ürünlerden öşür ${ }^{7}$ olarak, hayvanlardan ağnam vergisi ${ }^{8}$ olarak, madenlerden devlet hissesi olarak ve mal ticaretinden gümrük resmi olarak alınmaktaydı (Akgündüz, 1990:154). Devletin en önemli gelir kaynaklarından birisini Rüsum-u Şer’iye içerisinde yer alan cizye vergisi oluşturmaktaydı. İslam hukukuna göre, devletin Müslüman olmayan vatandaşını yakından ilgilendiren bir vergi olarak cizye başlangıçta Müslümanlığı kabul etmeyenlerden devlet tarafından can, mal ve ırzın korunması için alınırken sonradan Müslüman olmayanlardan askerlik görevlerini yerine getirmemeleri karşılığında alınan bir tür dereceli baş vergisi haline gelmişti (İnalcık, 1993: 45-46).

7 Onda bir anlamına gelen öşür reâyânın, tımarl sipahiye ödediği bir vergi türüydü. Özellikle hububat ürünleri üzerine konan öşür vergisi Müslüman tebaa tarafindan üretilen tarımsal ürünler üzerinden belli oranlarda alınırdı. Fakat zirai ürünlerden hatta bu ürünler dışında örneğin baldan da öşür vergisi alındığı görülmüştü. Genel olarak 10'da bir alınsa da bu oran toprağın sulanma, verimlilik, mahalli örf ve adetlere göre 5/1, 6/1, 8/1 oranlarında da alınırdı. Bkz. Kazıcı, 2003.

8 Osmanlı resmî kayıtlarında resm-i ganem, âdet-i ăgnâm şekillerinde de geçen bu verginin miktarı Fâtih kanununa göre üç koyundan bir akçe iken daha sonra iki koyundan bir akçe olarak tespit edilmişti. Ancak bu miktar bölgelerin özelliklerine göre değişebilmekteydi. Bkz. Emecen, 1988. 
Kaya, P.H. (2021), “Âdem-i Merkeziyetçilik-Merkeziyetçilik Tartışmaları Bağlamında Osmanlı Devleti ve Fransa'da Savaşlar, Mali Baskılar, Kurumsal Değişim”, Sosyoekonomi, 29(50), 433-463.

Osmanlı Devleti'nde örfi vergiler, din ayırımı yapılmaksızın herkesten yerel ve olağanüstü harcamaları karşılamak için alınan ve geleneklere göre konmuş düzensiz vergilerdi. Fakat daha sonraları bu vergiler devletin içinde bulunduğu şartlardan dolayı sürekli uygulanan vergiler haline gelmişlerdi. En temel Rüsum-1 Örfiye vergileri arasında, kullanılan toprağın miktarına göre nakit olarak toplanan diğer bir deyişle toprak kirası olan çift resmi; çift resminden farklı olmayan ancak gayrimüslim tebaadan alınan ispence; evlenen kız ya da kadınlar için erkeklerinden alınan arus; tımar topraklarında yaşayanlardan işledikleri suça karşılık alınan cürm-ü cinayet yer almaktaydı (Pamuk, 2010: 45). Osmanlı Devleti, XVII. yüzyılın başlarından itibaren savaş masraflarını hafifletmek için olağanüstü durum vergisi almaya başlamıştı. Avârız akçesi, nüzûl ve sürsat bedeli diye adlandırılan Avârız-1 Divâniyye ${ }^{9}$ türündeki bu vergiler, önce belirli savaş yıllarında istenirken, XVII. yüzyıldan itibaren giderek sürekli hale gelen Avusturya, İran, Venedik, Lehistan savaşları ve kapıkulu askerlerinin artan masrafları ve mevacip ödemelerinden dolayı kalıcı vergiye dönüşmüştü. Ayrıca, savaş döneminde savaşa katılan valilerin ihtiyaçlarını karşılamak için imdâd-î seferiye ve malikâne uygulaması sonucu gelirleri azalan valilerin sefer olmadığı barış dönemlerindeki giderlerini karşılamak için imdâd-î hazeriyye vergisi alınmaya başlanmıştı. (Kaya, 2017: 235).

Osmanlı Devleti'nde devlete ait vergi gelirleri, belirli vergi toplama usulleriyle vergilerin merkezi hazineye taşınması şeklinde doğrudan ve hasılatı doğrudan merkezi hazineye ait olmayan fakat mîrî bir vazife karşılığında askeri zümrelere bırakılmış vergilerin yine ilgili zümreler tarafından toplanması şeklinde dolaylı olmak üzere iki şekilde toplanmaktayd1. Doğrudan tahsilatla merkezi hazineye bağlı ve merkezi bütçe gelirlerinin esasını oluşturan havass-1 hümayun gelirleri elde edilirken dolaylı tahsilat ile devletin merkezi gelirleri içinde yer almayan tımar gelirleri elde edilirdi (Özvar, 2003: 2). Devletin tarımdan elde edeceği gelirin büyük bir kısmı tımar kesimi içerisinde belli gider alanlarına ayrılmaktaydı. Buna göre devlet, kendisi araya girmeden, tarımdan alacağı vergiyi, doğrudan doğruya büyük bir kısmı asker olan tımar sahiplerine bırakıyordu (Tabakoğlu, 2014: 65). Toprağın mülkiyeti padişaha aitken tımar sahibi olan sipahi, reâyâdan toprak rantı karşılığında vergi toplamakta ve karşılığında orduya belirli sayıda teçhizatlı savaşçı sağlamaktaydı. XVI. yüzyılda Osmanlı Devleti gelirlerinin üçte ikisi ila dörtte üçü tımar sisteminden geliyordu (Barkan, 1980: 806). XVII. yüzyılda vergi gelirlerini tımar düzeni çerçevesinde dolaylı olarak kullanmak yerine doğrudan merkezi hazinede toplama çabalarının sonucu olarak vergilendirme görevinin özel teşebbüs gibi hareket eden kişilere belirli şartlarda devredilmesine olanak sağlayan iltizam sistemi yaygınlaşmıştı. İltizam

9 Osmanlı Devleti merkez maliyesinin önemli bir vergi kalemi olan avârız-ı divaniye vergilerinin aynî, nakdî ya da hizmet şeklinde olmak üzere farkl türleri söz konusuydu. Kısaca avârı olarak bilinen bu vergiler Müslüman ve gayrimüslim fark etmeksizin tüm tebâdan alınırdı. Yol, köprü ve su yollarının bakım ve onarımından, saray mutfağı için tavuk ve soğan tedarikine, ordunun ihtiyacı olan harp malzemesini ve arpa, saman gibi ihtiyaç maddelerini tedarik etmeye, askerin geçeceği yollar boyunca tesis edilen menzillere belirlenen çeşit ve miktarda zahire satmaya, hisar yapmaya ve avârı akçesi ya da avârız bedeli akçe ile seferin masraflarına katılmak avârız vergilerinin başlıcalarındandı. Devletin içinde bulunduğu konjonktürel yapıdan dolayı avârız miktarı yıldan yıla hatta aynı yıl içerisinde bile değişiklik gösterebilmekte bu nedenle de avârız miktarı kanunnamelerde belirtilmeyip her yll fermanlarla belirlenirdi. Bkz. Kaya, 2017. 
Kaya, P.H. (2021), “Âdem-i Merkeziyetçilik-Merkeziyetçilik Tartışmaları Bağlamında Osmanlı

Devleti ve Fransa'da Savaşlar, Mali Baskılar, Kurumsal Değişim”, Sosyoekonomi, 29(50), 433-463.

sistemi; devletin, genellikle belirli bir mekanla sınırlı mukataa ${ }^{10}$ birimlerini vergilendirmeyi rekabete açık, müzayede ile tespit edilen ve bir bölümü peşin ödenmesi istenen belirli bir yıllık bedel karşılığında (bir ila üç yıl), sınırlı bir süre (tahvil) için kârı ve zararı kendine ait olmak üzere kabul edecek mültezimlere güvenilir bir kefaletle devretmesiydi. Mültezim sivil sektörden, reâyâ, yabancı ya da askerî zümre mensubu olabilirdi. İltizamda hazinenin ihtiyacına ve mültezimlerin rekabet gücüne göre değişmekle birlikte her zaman için bir peşin ödeme söz konusuydu (Genç, 2000: 154-155). İltizam sistemi, maaşlı devlet personeli yerine özel şahıslar tarafından yürütülen her türlü vergi tahsilatını ifade etmekteydi.

Fransız mali sistemi, XVI. yüzyılda Osmanlı Devleti'nin mali sistemi ile pek çok benzerliği paylaşıyordu ${ }^{11}$. $\mathrm{O}$ da karmaşıktı ve nispeten âdem-i merkeziyetçiydi. Fransa'da mali sistem; hakkında hiçbir şey bilinmeyen, hiç kimseye karşı sorumlu olmayan, karmaşık, bölgeden bölgeye değişen ${ }^{12}$ vergi oranlarına sahip ve nadiren kararnamelerde belirtilen ilkelere göre tahsilatın yapıldığ 1 bir sistemdi. Fransa'da vergilendirmenin kökeni XIV. yüzyıla dayanmakta ve dolaylı vergilerin özelleştirilmiş toplanması (iltizam) ile merkezi olmayan (âdem-i merkeziyetçi), yerel olarak kontrol edilen dolaysız vergilerin bir karışımı şeklindeydi (Markoff, 1996: 237). Dolaysız vergiler, kraliyet görevli memurları tarafından bireylerden alınan bir vergiydi. Özellikle memurlarda rüşvet alma yaygın olduğundan dolaysız vergiler için kesin bir vergi oranı yoktu. Dolaylı vergiler ise iltizam sistemi aracılığıyla fermiers-généraux adı verilen yolsuzlukları ve açgözlülükleri ile bilinen "iltizamcılar" tarafindan toplanıyordu. İltizam sistemi kapsamında, iltizamcı, sabit miktarın üzerinde toplanan herhangi bir vergi gelirine ilişkin kalan gelir karşılığında krallığa sabit bir ödeme yapmayı kabul etmişti. Osmanlı Devleti ile benzer şekilde Fransa'da da özel aracılarla vergilerin toplanması yaygındı. Dolayısıyla âdem-i merkeziyetçi yapı çerçevesinde vergiler doğrudan bireylerden toplanmak yerine iltizamcilardan toplu olarak alınıyordu. XVI. yüzyıl Osmanlısı'nda olduğu gibi aynı dönemde Fransa'da iltizam sisteminde tek bir şahıs olarak veya ortaklık halinde faaliyet gösteren bir kesim vardı. XVI. yüzyılın sonunda, iltizamlar kraliyet gelirlerinin yaklaşık üçte birini oluşturuyordu (Balla \& Johnson, 2009: 814).

Fransa'daki en eski eyalet vergisi, XV. yüzyılda ortaya çıkan, gelir ve servet üzerinden alınan ve ordunun ihtiyaçlarının karşılanması için tahsis edilen taille idi. Taille, yılda yaklaşık 20 milyon livre getiren, kraliyet hükümetinin en kazançlı vergisiydi. Fransa'nın bölgesine bağlı olarak, çeşitli gelir ve servet (özellikle arazi) ölçülerine uygulanmaktaydı. Ancak bu, keyfi olarak yapılırdı ve miktar yıldan yıla önemli ölçüde

10 Mukataa, iltizamın konusu olan vergi birimidir. Mukataa, bir yandan tek bir vergi türünü belli bir bölge veya bölgeler itibariyle kapsamına alabilirken diğer yandan da çeşitli vergi türlerini belli bir bölge veya bölgeler itibariyle kapsamına alabilmekteydi. Bkz. Genç, 2006: 129.

11 Osmanl Devleti'nin merkezi hazine gelirleri, Fransa ve İspanya dişındaki tüm Avrupa devletlerinden daha fazlayd. Bu durum XVI. yüzyllda Avrupa Devletleri karşısında askeri anlamda güçlü olmaslyla yakından ilişkiliydi. Bkz. Pamuk, 2014.

12 Örneğin, kişi başına ortalama dolaysız vergilendirme Brittany'nin bazı kısımları ile Guyenne'in bazı kısımları arasında \% 400 'e varan oranda farklllık göstermekteydi. Ayrica gabelle vergisi bölgeden bölgeye tuz fiyatının 10 katına kadar değişebiliyordu. Bkz. Peter, 1988. 
Kaya, P.H. (2021), "Âdem-i Merkeziyetçilik-Merkeziyetçilik Tartışmaları Bağlamında Osmanlı Devleti ve Fransa'da Savaşlar, Mali Baskılar, Kurumsal Değişim”, Sosyoekonomi, 29(50), 433-463.

değişebiliyordu. Taille, ilk olarak XV. yüzyılda Yüz Yıl Savaşları'nın masraflarını karşılamak için toplandı. XVI. yüzyılda, II. Henri döneminde posta servisi, savaş, yol ve köprü tamiri için kullanılmak üzere alınan crue, the grande crue ve taillon adlarında taille'yi tamamlayıcı vergiler yürürlüğe konulmuştu. Fransız Devrimi zamanında dolaysız vergi gelirlerinin yaklaşık \%45'ini bu vergi temsil ediyordu (Bloch, 1940: 267-268). Taille vergisi, Osmanlı Devleti'nde XVII. yüzyılda giderek daha düzenli bir vergi haline gelen avârız vergisine benzemekteydi (Pamuk, 2014: 7). Diğer dolaysız vergiler capitation (baş vergisi) ve vingtième idi. Capitation kişi başı, her yetişkin vatandaşa tahakkuk ettirilen bir "kelle vergisi" veya "baş vergisi" idi. İlk olarak 1695 yılında savaş döneminde yürürlüğe kondu. Bir livre ile 2.000 livre arasında değişen tutarlarda alınan bu vergiden din adamları muaftı (Kwass, 2000). XVI. yüzyılda ortaya çıkan aide royale vergisi, özellikle içecekler üzerinden alınan bir tüketim vergisi olmakla birlikte tüketim metalarının satışı ve nakliyesi üzerinden de alınmaktaydı. Gümrük vergisi olarak ithalat ve ihracat üzerinden alınan Traites ile birleştiğinde aides Bordeaux'da şarap fiyatını on kat yükseltmekteydi. Aslında bu bir satış vergisiydi ve antik rejimin laneti haline gelen dolaylı vergilendirme sistemi içerisinde yer alıyordu (Brissaud, 1915: 455-456). Gabelle ise tuz üzerinden alınan ve Fransa için önemli olan bir vergiydi. Kral Fransa'nın bazı bölgelerinde tuz üretim tekelini elinde bulunduruyor, tuz satışını denetimi altında tutuyordu. 1780'lerde gabelle, yılda 55 milyondan fazla livre gelir sağlayarak hükümetin vergi gelirlerinin \%10'undan fazlasını oluşturuyordu. Dolaylı vergiler, ortalama olarak, 1662 ile 1773 arasındaki vergi gelirlerinin neredeyse yarısını meydana getirirken esasen \%28'i alkollü içecekler (aides lerden biri), gabelle (tuz) ve tabac (tütün) vergilerinden oluşuyordu (Chanel, 2015: 68-69).

Fransa'nın vergilendirmeyle ilgili sorunları XIV. Louis (1643-1715) dönemine kadar uzanmaktaydı. Fransa'da taille ismindeki dolaysız vergiden soylular, kilise mensupları, bazı resmi kişiler ve bazı kentler muaf olduğu için yükün orta ve fakir sınıfın sırtına yüklü olması ile aide ve gabelle ile tütün tekelinin mültezimler elinde olması vergi sisteminin en önemli sorunlarıydı (Buluş, 2010: 97). Dolaylı vergilerin tek bir kişiye belirli miktar karşılığında verilmesi, iltizam bedelinin çok altında gelir elde edilmesine neden olmuştu. Osmanlı Devleti'nde olduğu gibi dolaylı vergilerin iltizama verilmesinde ihale yöntemi getirilmişti. İhale yöntemiyle iltizamlardan elde edilen dolaylı vergi miktarı artırılmıştı. 1681'de Maliye Bakanı Colbert, vergi tahsilatını "iltizamcı" sayısını azaltarak düzene sokma girişimi olarak General Farms'1 kurdu ve iltizamların hepsinin buraya devrini gerçekleştirdi. Böylelikle kendisinden önce görev yapan Fouquet (1650-1653) iltizam yöntemiyle 36,9 milyon livre elde etmişken, Colbert 65,8 milyon livre elde etmişti (Sargent, 2004: 18-23). General Farms'in \%10'u halktan, üçte biri yargı soylularından ve kalanı da diğer soylulardan oluşuyordu (Bossenga, 2003: 69-70). Bu iltizamcılar o kadar çok kâr elde ediyorlardı ki kentlerin en zenginleri finansörler ve vergi tahsildarları olmuştu (Hazan, 2015: 25).

Aşağıda açıklanacağı gibi, XVII. yüzyıl boyunca hem Osmanlı Devleti'nde hem de Fransa' da iltizam sisteminin önemi arttı. Fransa'da iltizam sistemi ile XVII. yüzyılın başında gelirlerin yaklaşık üçte biri toplanırken XVIII. yüzyılın başında gelirlerin yarısına yakınını toplandı. Benzer şekilde, Osmanlı Devleti'nde de XVIII. yüzyılın başında iltizam, devlet gelirlerinin yaklaşık yüzde 30 ila 50'sini oluşturuyordu (Salzmann, 2004: 105). Bununla 
Kaya, P.H. (2021), “Âdem-i Merkeziyetçilik-Merkeziyetçilik Tartışmaları Bağlamında Osmanlı

Devleti ve Fransa'da Savaşlar, Mali Baskılar, Kurumsal Değişim”, Sosyoekonomi, 29(50), 433-463.

birlikte, iltizam sisteminin her ülkede nasıl geliştiği konusunda da önemli farklılıklar vardı. Fransa'da, iltizam sistemi, General Farms Şirketi olarak bilinen, yarı özel, tek bir organizasyonda birleştirildi. Şirket, XVIII. yüzyılda Fransız mali sisteminin en etkili paydaşlarından biri haline geldi ve bu konumunu büyük bir başarıyla korudu. İlerleyen kısımlarda daha detaylı ele alınacağı üzere tımardan başlayıp sırasıyla iltizam ve malikâne usullerinin uygulanması, dönemin ihtiyaçları gereği XVII. ve XVIII. yüzyıllarda Osmanlı Devleti'nin daha fazla âdem-i merkeziyetçiliğe doğru ilerlediği ve devletin vergi tahsildarı durumundan kontrolörü durumuna geçmesi olarak düşünülebilir (Katıranc1, 2015: 1). Osmanlı Devleti ile karşılaştırıldığında XVIII. yüzyıl Fransa'sında mülkiyet haklarının mali sözleşmeler üzerindeki göreceli güvenliğini nasıl açıklayabiliriz? Daha spesifik olarak, Osmanlı Devleti'nde General Farms gibi bir koalisyon ortaya çıkmamışken Fransız mali sistemi içinden dayanıklı ve güçlü bir siyasi koalisyonun ortaya çıkmasına ne sebep oldu?

\section{Savaşların Illtizam Sistemine Etkileri}

XVI. yüzyıldan sonra Avrupa ve Orta Doğu'daki iltizam sistemi biçimleri benzer yasal temellere sahip olsa da uygulamalar dünya çapındaki yeni eğilimlerle, yani artan savaş maliyetleri ve genişleyen küresel ticaretle değişikliğe uğramıştı. Osmanlı Devleti’nin XVIII. yüzyıl öncesi tarihine bakıldığında devletin kurumlarının, yapısının kısacası genel sistematiğinin savaşlar üzerine biçimlenmiş olduğu ve ekonominin kendini yeniden üretmesinde bu savaşların çok önemli rol ve işleve sahip olduğu görülmekteydi. Osmanlı klasik düzeni içerisinde savaşlar bir bunalım öğesi değil tam tersine bir kazanç kaynaği idi. O halde burada şu soruyu sorabiliriz: Yılları savaşlarla geçmiş ve bu savaşları yıllarca bir kazanç kaynağı olarak görmüş Osmanlı Devleti'nde bu savaşlar artık nasıl da kaçınılmaz bir mali bunalım öğesi olmaya başlamıştı? Başka bir deyişle XVIII. yüzyılla birlikte nasıl bir değişim ve dönüşüm süreci yaşanmıştı ki, savaşlara göre biçimlenmiş eski Osmanlı düzeni sarsılarak mali bunalımlar yaşanmaya başlanmıştı (Cezar, 1986: 27-28).

XVII. yüzyıla kadar tımar sistemi, bir tür vergi-maaş sistemi olarak eyalet askerini finanse ederken XVII. yüzyılla birlikte Alman ve Avusturyalıların yeni bir ordu düzeni içinde ateşli silah kullanan piyade askerlerine karşı Osmanlı Devleti sipahilerinin etkisiz kalması tımar sisteminin mecburen değişim sürecine girmesine neden oldu. Osmanlı Devleti, ateşli silah kullanabilen gençleri paralı asker olarak istihdam etmeye başladı. Bu süreç, merkezi ve ücretli ordunun gittikçe daha önem kazanması anlamına geliyordu. Diğer yandan bu durum devlet maliyesi açısından ciddi sonuçlar doğuracaktı. XVII. yüzyılda devlet maliyesi açısından en az bu süreç kadar ciddi sonuçlar doğuracak başka bir gelişme ise, uzun süren savaşlar ve bu savaşların finansmanıydı (Özvar, 2003: 10-13). 1645'te başlayan ve 1669 yılında biten Girit Savaşı ile Osmanlı Devleti’nde uzun ve masraflı savaşlar dönemi başlamış oldu. Devamında Avusturya Savaşı, 1672-1676 Lehistan Savaşı, 1678-81 Rusya Savaşı, 1683 yılında yeniden Avusturya ile savaşa girmesi ve peş peşe kaybettiği savaşlar ve 1699 yılında imzaladı̆̆ı Karlofça Antlaşması Osmanlı maliyesini kronik bütçe açıklarına sürüklemişti (Cezar, 1986: 32). Savaş ve yarattığı finansal ihtiyaçlar, erken modern kamu maliyesindeki kurumsal değişimin arkasındaki itici güçtü. 


\section{Grafik: 1}

\section{Osmanlı’da 1600-1785 Dönemi Bütçe Gelir ve Giderleri (Akçe)}

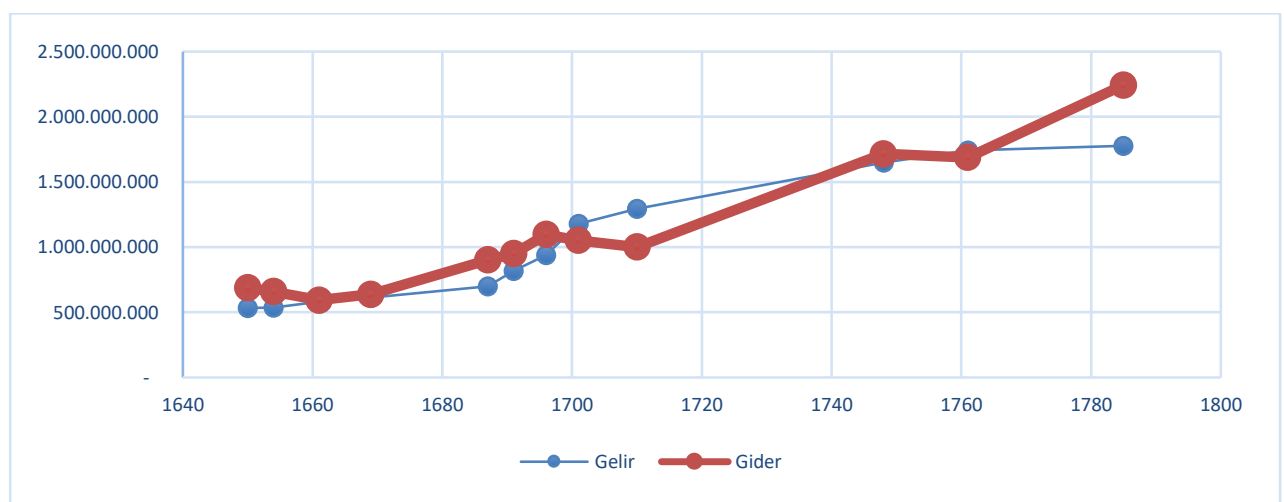

Kaynak: Tabakoğlu, 1985a:15-16; Genç, 2009: 223.

Bu dönem savaşlarının Osmanlı Devleti'ne getirmiş olduğu yükün bütçeye etkisi literatürde bu konuyla alakalı yapılan çalışmalardan da görülebiliri ${ }^{13}$. Grafikten de anlaşılacağı üzere mali bunalım süreci XVII. yüzyıldan itibaren etkisini artırarak devam etmiş ve genellikle savaş dönemlerinde bütçe açık vermişti. İlk zamanlar düşük seviyelerde seyreden bütçe açıkları, sonrasında büyüyerek kronik hale gelmişti.

Vergi gelirlerinin büyük bir kısmı askeri amaçla harcandığından Osmanlı Devleti’nin maliyesi savaş dönemlerinde ağır baskı altına girdi. Bu mali baskı dönemleri, Osmanlıların mali kurumlarını değiştirdiği ya da vergi tahsilatında, iç borçlanma ya da yeni gelir kaynakları için tamamen yeni kurumlar benimsediği kilit dönemlerdi (Pamuk, 2014: 7-8). XVII. yüzyılda tımar sisteminin bozulması, uzun süren ve genellikle kaybedilen savaşlar ve içeride yaşanan iç karışıklıklar nedeniyle devlet savaş masraflarını karşılayamaz duruma gelmiş ve Osmanlı devlet hazinesinde paraya olan ihtiyaç gittikçe artmıştı. 1695 yılından itibaren, özellikle maliyenin artan nakit ihtiyacının karşılanması için iltizam ile işletilen mukataalar malikâne haline getirilmeye başlanmıștı. Diğer yandan da savaş harcamalarını karşılamak üzere olağanüstü vergiler konulmuştu. XVIII. yüzyılda "imdâd-î seferiye" ve "imdâd-î hazeriyye" adında yeni vergiler konularak, vali ve sancakbeylerinin çeşitli yükümlülüklerinden kaynaklanan giderlerine karşllık olmak üzere kendilerine tahsis olunmuştu. Diğer bir deyişle, imdâdiyeler vali ve sancakbeylerin iltizam sistemindeki değişiklikler nedeniyle giderek yoksun kaldıkları eski has gelirlerinin bir tamamlayıcısı biçimindeydi (Kaya, 2017: 218-219).

Fransa'da XIV. Louis'nin son otuz yılında gerçekleşen savaşlar Colbert'in devletin gelirlerini artırmaya yönelik çabalarını boşa çıkarmıştı. 1715 'te XIV. Louis ölmüş, İspanya Savaşı bitmiş geride büyük miktarda borç kalmıştı. Fransa'da, harcamalar savaştan hemen

13 Bu bütçeler için bkz. Barkan, 1955; Tabakoğlu, 1985b; Sahillioğlu, 1969. 
önce veya savaş esnasında artmanın yanı sıra harcamaların büyüklüğü birbirini izleyen her krizle daha fazla artmıştı.

Grafik: 2

Fransa'da 1725-1760 Dönemi Bütçe Gelir ve Giderleri (Milyon Livre) ${ }^{14}$

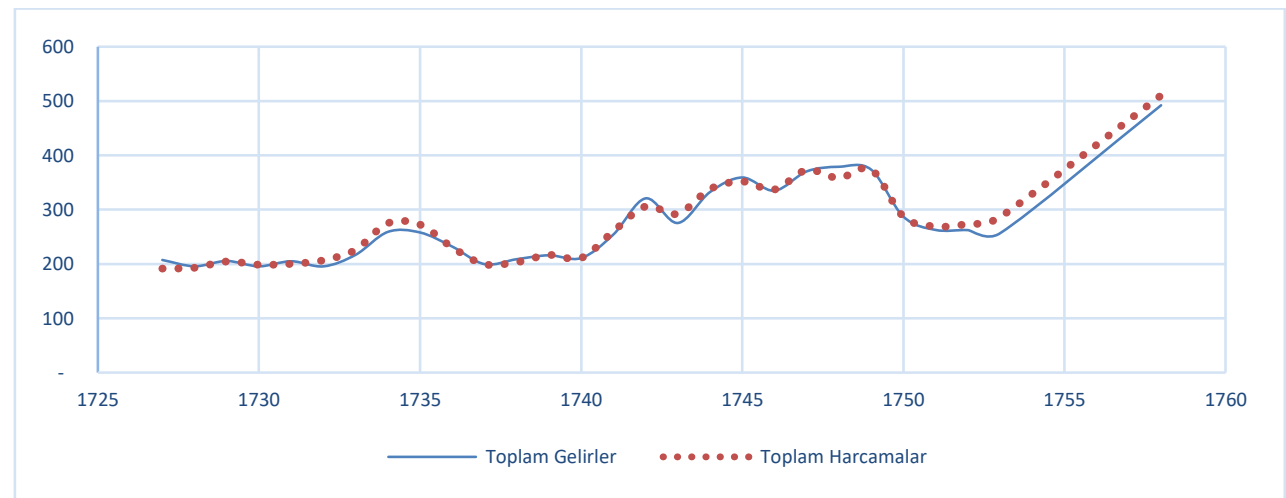

Kaynak: Riley, 1987: 224-225.

Savaş zamanı harcamaları Polonya Veraset Savaşında (1733-35, mali 1734-35) 259 milyon livreden Avusturya Veraset Savaşında (1740-48, mali 1741-49) 379 milyon livreye yükseldi. Yedi Y1l Savaşları'nda ise (1756-63, mali 1756-62) en az 506 milyon ile zirveye ulaştı (Riley, 1987: 228). 1733-1736 yılları arasında kral tahvile benzeyen rentes viageres'leri çıkararak kiliseden, pays d'etat'lardan ve receveurs des finances'den borçlanmıştı. Askeri harcamalar bütçenin en büyük harcama kalemini oluşturuyordu. Avusturya Savaşı ile birlikte capitation vergisine ek olarak 1749'da toprak sahiplerinin net geliri üzerinden $\% 5$ oranında alınan vingtième adında vergi getirildi. İkinci vingtieme, 1756 yılında yürürlüğe kondu ve Yedi Yıl Savaşları boyunca uygulanmasına devam edildi. Kral, Yedi Yıl Savaşı'nın maliyeti karşılamak için yüzde on faiz oranı ile borç almak zorunda kalmış ve zamanla borçlar bütçenin beşte ikisinin oluşturur duruma gelmişti (White, 2001: 16).

14 Grafikte yer alan bütçe gelirleri; taille ve capitation (baş vergisi) vergi gelirleri, General Farm ve diğer çiftliklerinden gelen gelirleri, monarşi tarafindan düzenli olarak alınan diğer vergileri ve kraliyet alanlart tarafindan sağlanan bazı vergi dışı gelir kaynakların içermekteydi. Bunlara daha sonra, Polonya Veraset Savaşı ve Avusturya Veraset Savaşı sirasinda gelirin onda biri olan dixieme vergisi ve 1750'de yirmide biri olan vingtieme vergisi eklendi. Yedi Yıl Savaşları sırasında iki vingtieme vergisi daha tanıtıldı. Gelir üzerindeki tüm harçlar, olağanüstü gelirler ve olağanüstü işler altında rapor edilirdi. Böylece vergiler iki kategoriye ayrılabilirdi. Birincisi, olağan gelirleri sağlayan dolaysız ve dolaylı vergiler, kralın her yll vergi alma hakk vardl. İkincisi, savaşla özdeşleş̧tirilen özel harçlar, ancak 1750 yll vingtieme örneğinde olduğu gibi sadece savaş değil sonrasında barış döneminde de alınmaya devam etti. Dixieme ve vingtieme 1740'tan sonra o kadar düzenli bir şekilde alınıyordu ki, bazı yetkililer bunun olağan bir vergi haline geldiğini savundular. Bu dönemde hem olağan hem de olağanüstü gelirler arttı. Bkz. Riley, 1987. 


\section{Grafik: 3}

\section{Fransa'da 1760-1788 Dönemi Bütçe Gelir ve Giderleri (Milyon Livre)}

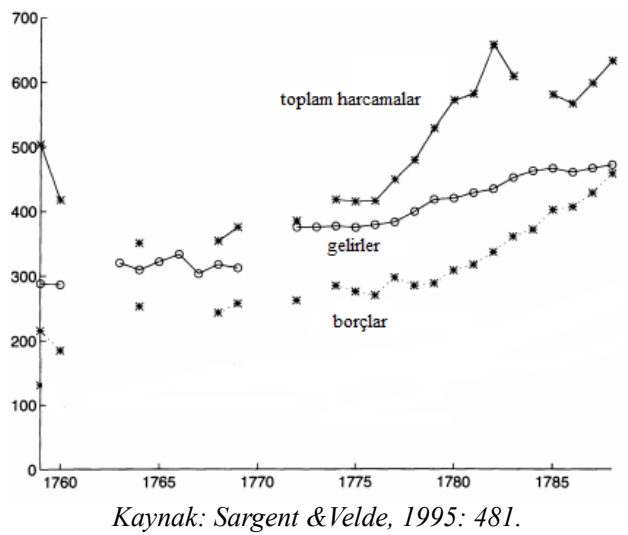

1726'dan 1789'a kadar savaş harcamaları üç kat artmış, gelirler de buna yaklaşık bir oranda artsa da savaşlar için yapılan harcamalar borçların ağırlığı nedeniyle gelirleri bastırmıştı. 1788 yılında borçları ödemek için toplam yıllık 120-130 milyon livre gerekmişti. Parlement'eye 1763, 1772 ve 1781 yıllarında barış dönemleri için vingtieme vergisi yürürlüğe koyması için bask1 yapılmıştı (Norberg, 1994: 268-270). Colbert'ın iltizam sistemini merkezileştirmesi pek işe yaramamış, iltizam alt sözleşmelerle farklı vergi tahsildarlarına verilmişti. Savaş dönemi dolaylı vergiler yürürlüğe girmiş, bu vergiler genel iltizama değil, parçalı halde iltizama verilmişti. Bu durum vergilerin $\% 10$ artırılmasına neden olmuştu (Velde, 2006: 8-10). Necker yönetimi harcamaların karşılanmasına yönelik olarak borçlanma yoluna gitmişti. Bunu yapmanın en basit yolu, iltizamıının, kira bedelinin ödemelerini vadesi gelmeden önce krala iletmesiydi. Bu tür erken ödemelere gelecekteki vergi makbuzları için tahmin deniyordu. Kral yaklaşı 2.000.000 livre'lik gelecekteki ödemeler beklentisiyle en az 1.668.212 livre borç aldı. Böylece kral, makbuzlarının yarısını aides toplanmadan önce tahsil ediyordu (Balla \& Johnson, 2009: 818). Kralın General Farms'a 68,4 milyon livre borcu bulunmaktaydı (Bossenga, 2003: 69-70).

Özellikle savaş dönemlerinde savaş harcamalarını karşılamak için olağan vergilerin yanında olağanüstü vergilerin alınması bunların oranlarının artırılması mali anlamda her iki ülkeyi de bir krize sürüklemiş, mülkiyet hakları üzerinde artan belirsizlikler yaratmıştı. Giderek artan harcamalar ve sabit gelirlerle karşı karşıya kalan Osmanlı Devleti ve Fransız yönetimi bir yandan mali sözleşmelerde daha fazla borçlanmaya giderken diğer yandan mülkiyet haklar1 ${ }^{15}$ üzerindeki artan belirsizliğin kurumsal gelişime etkisi her iki ülkede çok farkliydı (Potter, 2003: 132-134).

15 Fransa'da mali kurumların mülkiyet haklarl uzun vadede artırllırken, Osmanlı Devleti'nde böyle bir durum gerçekleşmedi. Savaş harcamalarındaki artışlar her ülkede aynı etkiyi yaratmadı. Bkz. Potter, 2003. 
Kaya, P.H. (2021), “Âdem-i Merkeziyetçilik-Merkeziyetçilik Tartışmaları Bağlamında Osmanlı

Devleti ve Fransa'da Savaşlar, Mali Baskılar, Kurumsal Değişim”, Sosyoekonomi, 29(50), 433-463.

Osmanlı Devleti'nde merkezi ordunun önem kazanması, seferlerin uzun sürmesi ve buna bağlı olarak nakit ihtiyacının artması karşılığında Osmanlı Devleti maliyesinin aldığı en önemli tedbirlerden biri iltizam sisteminden malikâne sistemine geçerek tımar alanlarında mukataalaşma eğiliminin artmasıydı. İltizam sistemindeki bu gelişmeye paralel başka bir uygulama ise peşin uygulamasının gittikçe yaygınlık kazanmasıydı. İltizam uygulamasında mültezimlerin yüklenecekleri mukataalar için hazineye ödedikleri bir tür teminat ya da kefalet bedeli olan peşin, aslında erken dönemlerde vardı. Ancak bu süreçte yaygınlaşarak peşin, hazinenin nakit ihtiyacını bir tür iç borçlanma yoluyla karşılamanın önemli bir aracı haline gelmişti (Özvar, 2003: 17). Bu uygulama Fransa'da Kral'ın gelecekteki gelirlerini önceden borçlanmasına benzer bir uygulama olarak karşımıza çıkmaktadır.

Sonuç olarak, XVII. ve XVIII. yüzyıllarda iltizam sistemi vergi toplamanın birincil yöntemi haline gelerek merkezi hazinenin en önemli gelir kaynağı olmuştu. Ancak Fransa'da olduğu gibi Osmanlı Devleti'nde de iltizam sözleşmelerinde belirsizlikler söz konusuydu. Mukataalar tahvil süreleri dolmadan defalarca hazineye gelir sağlamak amaciyla başka mültezimlere verilmişti. XVII. yüzyılda 206 iltizam sözleşmesinin \%10’u bir yıldan kısa süre içinde iptal edilmişti. 1618 yılında Selanik Tuz Fabrikası için bir yıl içinde dört farklı iltizam sözleşmesi yapılmıştı (Çizakça, 1999b: 224). Diğer taraftan yüklenilen bir mukataa için süresi içinde başka bir mültezim tarafından daha yüksek bir teklif verilirse mevcut mültezim ya aradaki farkı ödeyerek yüklenmeye devam edecekti ya da sözleşmesi fes edilecek ve yeni mültezimle yeni bir iltizam sözleşmesi yapılacaktı (İnalcık, 2000). Tüm bunlar, iltizam sözleşmeleri üzerindeki mülkiyet haklarının belirsizliğini artırdı.

\section{Belirsiz Mülkiyet Hakları ve Kurumsal Değişim}

Osmanlı Devleti'nde de mültezimler hukuken padişaha karşı sorumluydu ve hesapları düzenli olarak kontrol ediliyordu. Fransa'da olduğu gibi, bazı vergileri toplamak için neden tımar sözleşmelerinin kullanıldığı ve diğer durumlarda neden iltizam sözleşmelerinin tercih edildiği, vergi gelirlerini ölçmenin ve izlemenin işlem maliyetleri ile açıklanabilmekteydi. Esas itibariyle merkeze bağlı bürokrasi ile yine merkezin emrinde bulunan sipahilerin yüklendikleri bu faaliyetleri, devletin yüzlerce kilometre uzakta bulunan yerlerinden toplanacak ayni vergileri, doğrudan doğruya toplamak imkânsız olduğu için, vergilerin nakden alınması veya nakde çevrilerek merkezi bir hazineye aktarılması ve oradan bu faaliyet zümrelerine maaş şeklinde ödenmesi gerekliliği ortaya çıktı. Bu nedenle daha önce de bahsedildiği gibi tımar sisteminden iltizam sistemine geçiş yapılmıştı (Genç, 2009: 102).

XVII. yüzyılın ilk yarısında hem Fransa hem de Osmanlı Devleti'nde âdem-i merkeziyetçi vergi sistemleri vergi tahsildarlarının kralın sözleşmelere müdahalesine karşı direniş göstermelerine yardımcı oldu. Ancak Fransa ve Osmanlı Devleti'nin giderek belirsizleşen mülkiyet haklarına uzun vadeli tepkileri çok farklıydı. Fransa'da, 1661'den sonra krallığa karşı bir iltizamcılar koalisyonu ortaya çıktı. Bu koalisyon, iltizamcıların kralı tehdit etmesine olanak sağlayan mevcut kurumların sermaye havuzlamasına elverişli olması nedeniyle ortaya çıktı. Osmanlı Devleti'nde mevcut kurumlar sermayeyi bir araya getirmeye 
Kaya, P.H. (2021), “Âdem-i Merkeziyetçilik-Merkeziyetçilik Tartışmaları Bağlamında Osmanlı Devleti ve Fransa'da Savaşlar, Mali Baskılar, Kurumsal Değişim”, Sosyoekonomi, 29(50), 433-463.

yatkın değildi, bu da mali ajanların padişahı sınırlandırmak için yeterince büyük sayıda örgütlenmesini engelliyordu. Neden Fransa'da XVII. yüzyılın ikinci yarısında bir mali ajanlar koalisyonu ortaya çıktı ama Osmanlı Devleti'nde böyle bir koalisyon olmadı? İlk olarak, Fransız iltizamcılar daha homojen bir grup olarak yola çıkmışlardı. XVII. yüzyılın Fransa'sında, daha az iltizamcı, daha az iltizam vardı ve çiftçiler benzer sosyal ağlara mensuptu (Balla \& Johnson, 2009: 826-827). Osmanlı Devleti'nde ise bunun tersine, XVIII. yüzyıl boyunca, İstanbul'daki 1000 ila 2000 merkezli kişi ile şehirlerde bulunan yaklaşık 5000 ila 10.000 kişi ve sayısız müteahhit, finansör, muhasebeci ve yönetici devlet gelirlerinin önemli bir bölümünü kontrol ediyordu (Pamuk, 2014: 10). Homojenlik, en azından başlangıçta General Farms Şirketi’nin kurulmasını kolaylaştırdı. Osmanlı Devleti coğrafi olarak çok büyük olduğu için iltizamları Fransa'da olduğu gibi konsolide etmek mümkün olmayabilirdi. Ancak tek başına coğrafya, Osmanlı Devleti’nde neden her biri padişahı sınırlayabilen birden fazla mültezim koalisyonunun ortaya çıkmadığını açıklamıyordu. Çiftçiler, örneğin bir Mısır konsolide çiftliği veya Avrupa toprakları üzerinde büyük bir çiftlik oluşturarak bölgesel hatlar boyunca örgütlenebilirlerdi (Balla \& Johnson, 2009: 828). Bir başka olasılık da XVII. yüzyılda Osmanlı Devleti'nde mültezimlerin bir sınıf olarak birleşmenin toplu eylem maliyetlerini aşacak kadar homojen olmamasıydı. Fransa'da, özellikle 1661 sonrası dönemde, iltizamcıların çoğunun akraba ya da arkadaş olduğuna dair çok sayıda kanıt vardı. XVIII. yüzyılda, Fransız iltizamcılarının büyük çoğunluğu üst burjuvaziden geldi, Paris'te yaşadı, aynı kitapları okudu, aynı operalara ve aynı kiliselere gitti (Johnson, 2006: 2-4).

Aksine, Osmanlı mültezimleri devletin çeşitli etnik ve dini yapısını yansıtıyordu: İltizam sistemi içerisinde XVI. yüzyıldan XVIII. yüzyılın başlarına dek mültezimlerin dini kimlikleri açısından bakıldığında Müslüman mültezimlerin daima sayı olarak daha fazla olduğu görülmekteydi. Kendi içinde, gayrimüslimlerin (Hıristiyanlar ve Yahudiler) sayısı XVI. yüzyılın başından XVII. yüzyılın başına kadar artsa da bu tarihten itibaren azalma söz konusuydu (Özvar, 2003: 18). 1611 ile 1630 arasındaki sözleşmelere konu olan 96 mültezimin \%60'ı Müslüman, \%27'si Yahudi ve \%13'ü Hıristiyan idi (Çizakça, 1999b: 136). XVIII. yüzyıl Osmanlı iltizamcıları, Fransız meslektaşlarının homojen geçmişlerini paylaşmıyorlardı. XVII. yüzyılın başlarından itibaren Müslüman mültezimler arasında askeri zümre mensuplarının nispi oranının ciddi şekilde artış kaydettiği görülmüştü. XVIII. yüzyılda ise bu homojenlik yerini heterojen bir grup olarak askeri zümre, din adamları ve bürokratlara bırakmıştı (Özvar, 2003: 18). Bununla birlikte, İslam hukuku altında hükümdarla uğraşmak, önemli miktarlarda sermayenin bir araya getirilmesinde potansiyel olarak ciddi engeller oluşturuyordu.

Diğer bir neden de Fransızların Osmanlılara göre tüzel kişiliğe sahip, devredilebilir hisselerle yeni bir organizasyon oluşturmayı nispeten kolaylaştıran kurumlara sahip olmasıydı. Bu tür kurumlar, General Farms Şirketi'nin, kralla olan meselelerinde krala karşı örneğin kredileri keserek cezalandırmak için yeterli sermaye biriktirmesine izin verdi. On çiftçiden oluşan bir konseyin bir krediyi kesmeye karar vermesi, binlerce yatırımcının karar vermesinden daha kolaydı 1590 ile 1653 arasında, Fransız iltizam çiftlikleri birleştirilmeden önce, Fransız iltizam sözleşmelerinde yaklaşık 303 farklı imza bulunabilirdi. Bu çiftçilerden 
81'i birden fazla sözleşme imzaladı. 1600 ve 1652 yılları arasında -General Farms Şirketi'nin kurulmasından önce- en büyük iki iltizam, tüm iltizam sisteminden krala giden toplam gelirin yaklaşık \%52'sini oluşturuyordu (Balla \& Johnson, 2009: 827).

\section{Tablo: 1}

\section{General Farms Şirketi Kira Sözleşmeleri}

\begin{tabular}{|l|c|l|c|}
\hline Kefil & Yıl & Yıllık Kira Fiyatı (Livre) & Iltizamc Sayısı \\
\hline Carlier & 1726 & $80,000,000$ & 40 \\
\hline Desboves & 1732 & $84,000,000$ & 40 \\
\hline Forceville & 1738 & $91,830,000$ & 40 \\
\hline La Rue & 1744 & $92,000,000$ (barış dönemi) & 40 \\
\hline & 1748 & $91,153,000$ (savaş dönemi) & \\
\hline Girandin & 1750 & $104,265,000$ & 60 \\
\hline Henriet & 1756 & $110,000,000$ & 60 \\
\hline Prevost & 1762 & $124,000,000$ (barış dönemi) & \\
\hline & 1764 & $118,000,000$ (savaş dönemi) & 60 \\
\hline Alaterre & 1768 & $132,000,000$ & 40 \\
\hline David & 1774 & $152,000,000$ & 40 \\
\hline Salzard & 1780 & $122,900,000$ & \\
\hline Mager & 1786 & $144,000,000$ & \\
\hline
\end{tabular}

Kaynak: White, 2001: 6.

XVIII. yüzyılda kira sözleşmeleri, gabelle, tobacco (1747'den sonra), traites (iç ve dış gümrükler), aides, domaines vergi gelirlerini kapsıyordu. En çok gelir aides'lerden gelirken en az geliri traites ler getiriyordu. Vergi oranları 1705 ile karşılaştırıldığında 1781 'de \%50 daha yüksekti (Matthews, 1958: 70). General Farms Şirketi kurulduktan sonra 1681-1708 dönemi için iltizamcıların sayısı azalarak 88'e indi. 1726-1786 döneminde ise tablodan da görülebileceği üzere daha da azaldı, 1726'da 40 iltizamcı bulunuyorken bu sayı 1760'larda 60'a çıktı, 1786'ya gelindiğinde 42'ye düştü. Kira fiyatları ise 1726'da 80 milyon livreden 1786 yılında 144 milyon livreye yükselmişti. Bununla birlikte iltizamların yıllık kira fiyatları barış dönemlerinde savaş dönemlerine göre çok daha fazla idi. Örneğin, 1744 yılında 92 milyon livre iken, 1748 yılında Avusturya Veraset Savaşları döneminde yıllık kira fiyatları önceki dönemlere göre çok daha azdı (White, 2001: 6).

Matthews'e göre iltizam sistemi çok maliyetliydi. General Farms Şirketi'nin 1726 yılından sonra neredeyse hiç kayıp riski yoktu. Hükümetle yaptığı sözleşmelerden çok daha fazlasını toplayarak kâr elde ediyordu. 1774-1780 dönemde 40 iltizamcının her biri yıllık 24.000 livre maaş, harcamaları için 4.200 livre, 133.000 livre sermayesine faiz, 156.000 livre kâr payı elde ediyordu. Bu durumda burada şu soruyu sorabiliriz: O zaman neden devlet böyle maliyetli bir sisteme devam etti? Çünkü şirket özerk ve hala kraliyet mali yapısının vazgeçilmez bir parçası idi. Para olarak dolaşıma sokulan banknotlar yayarak halktan borçlandı (1762'de 60.000.000 livre), hükümet tarafından öngörülen makbuzlara karşılık gelen çekleri ödedi, ödenen devlet fonlarını topladı ve hükümete 1768-80 döneminde 92.000.000 livre kadar uzun vadeli borç verdi (Matthews, 1958: 191).

Neden Osmanlı Devleti'nde "doğal” kişiliğin aksine "yasal” bir kavram ortaya çıkmadı? Osmanlı Devleti'ndeki siyasi otorite Fransa'ya göre meşruiyet açısından dini otoritelere daha fazla bağımlıydı. Ekonomik yasalar, müftü ve kadı gibi dini liderlerin öğretilerine dayandığı için, bu yasaları değiştirmenin maliyeti İslam ülkelerinde çok daha 
Kaya, P.H. (2021), “Âdem-i Merkeziyetçilik-Merkeziyetçilik Tartışmaları Bağlamında Osmanlı Devleti ve Fransa'da Savaşlar, Mali Baskılar, Kurumsal Değişim”, Sosyoekonomi, 29(50), 433-463.

yüksekti (Balla \& Johnson, 2009: 831). Osmanlı Devleti'nde kurumsal kurumların yokluğunun ikinci bir nedeni ise vakıfların varlığı ve ikame gücüydü. Vakıf deyim olarak, bir kimsenin mülkünü sosyal veya dinî bir amaca sınırsız olarak tahsis etmesidir. XVIII. yüzyılda vakıf kurucularının \%80-90'ını askeri zümre mensupları, \%10-20 kadarını ise reâya oluşturmaktaydı. Vakıf sistemi ülkedeki sağlık, eğitim, diyanet, sosyal yardım ve bayındırlık yatırımlarını yürüten kurum olarak mali sistemin önemli bir parçasıydı (Kaya, 2017: 72). Yine de vakıf, tüzel kişiliğe sahip olmadığı, devredilebilir hisselerden yoksun olduğu, belirli bir amaca hizmet ettiği ve bu amaçtan sapmaması gerektiği için normal bir şirketten çok farklıydı. Geleneksel bir vakfa yatırılan sermaye, gerçek anlamda, işletmenin kuruluşunda ortaya konan amaca bağlıydı ${ }^{16}$.

\section{Şekil: 1 \\ Ortadoğu ve Batı Avrupa'da Örgütsel Farklılık}

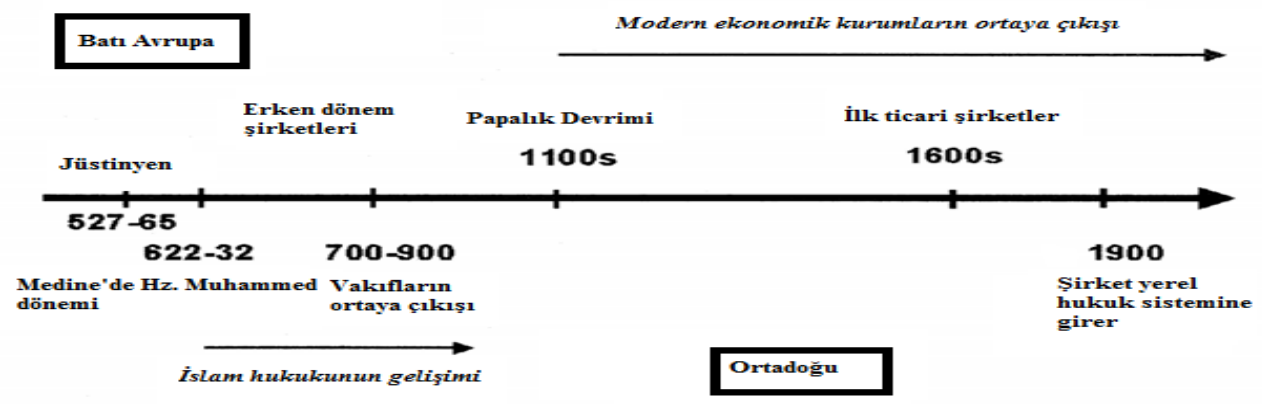

Kaynak: Kuran, 2005: 803.

Müslümanlar, İslam’ın ilk dönemlerinden beri sermaye ihtiyaçlarını mudârebe, müfâvaza, müşareke (inan ortaklığı) ve kredi ortaklığı (vücûh) diye bilinen iş ortaklıkları başta olmak üzere karz-1 hasen, para vakıfları vb. gibi bir takım faizsiz yollarla başarılı bir şekilde karşılamışlardı. Başta mudârabe olmak üzere Müslümanların geliştirdikleri ve para vakıflarında, gemicilik ve gemi yapımında ve daha çok da devlete finansman sağlayan girişimcilerin kurduğu iş ortaklığı türleri hem istihdamın artırılmasında hem de sermaye ihtiyacının karşılanmasında önemli bir rol üstlenmişti. Osmanlı Devleti’nin yanı sıra Ortaçağ

16 Klasik İslam hukuku, vakıf gibi önemli bir istisna dışında, bireylerin bütünlüğünden oluşan hiçbir ekonomik varlı̆̆ tanımaz. Ancak vakıf bile bir şirketin sahip olduğu birçok özgürlükten yoksundu. Sermayenin bir vakıf altında bu "hareketsizleştirilmesinin" kurumsal değișimi nasıl etkilediğinin çarpıcı bir örneği olarak Orta Doğu'da vakıf finansmanll medreseler olarak kurulan kolejler ile Batı'da eşzamanlı olarak kurulan üniversiteler arasındaki zıtlıklar verilebilirdi. Avrupa'da erken dönemde kurulan Paris (1180) ve Oxford (1240) üniversiteleri vakıf benzeri vakıf araçları altında oluşturulmuş ancak birleşme yoluyla hızla kendi kendini yöneten ve kendini yenileyen kuruluşlar haline geldiler. Buna karşılık vakıflar aracılı̆̆ıyla finanse edilen medreseler kurucularının direktifleriyle kisitlanmaya devam ettiler. Bu nedenle, zamanla, medreselerde müfredat üniversitelere göre daha az değişti ve Orta Doğu'nun entelektüel bir durgunluğa dönüşmesine neden oldu. İslami yönetim altında birkaç parlak yüzyıldan sonra Ortadoğu'nun entelektüel öneme sahip olmamasına birçok faktör katkıda bulunsa da temel neden vakıfların örgütsel sınırlamalarında yatmaktadır. Bkz. Kuran, 2005 . 
Kaya, P.H. (2021), “Âdem-i Merkeziyetçilik-Merkeziyetçilik Tartışmaları Bağlamında Osmanlı

Devleti ve Fransa'da Savaşlar, Mali Baskılar, Kurumsal Değişim”, Sosyoekonomi, 29(50), 433-463.

Avrupa'sında da yine bu amaçlarla çeşitli iş ortaklıkları gelişmişti (Çizakça, 1999b:115118).

Ticari canlanmanın Ortaçă̆ Avrupa'sındaki şirketleşme hareketine verdiği teşvik göz önüne alındığında, tüccarların yasal dönüşüme katkıda bulunması şaşırtıcı değildi. XVI. yüzyılın sonlarına kadar ticari işletmeler şirket olarak örgütlenmeye başlamadı. Bununla birlikte, ticari şirket ile ilişkilendirilen organizasyonel özellikler ve işleyişi için gerekli olan uygulamalar, önceki üç yüzyıl içinde çoktan ortaya çıkmıştı (Kuran, 2005: 802-811). Ortaçağda özellikle 12. ve 13. yüzyıllarda yaygınlaşan iş ortaklıklarının en önemlisi commenda ${ }^{17}$ idi. İngiltere, Kanada, Amerika Birleşik Devletleri ve Japonya gibi bazı ekonomilerde küçük ve orta ölçekli girişimcilerin işsizlikle mücadele ve finansman ihtiyacını karşılama çerçevesinde gündeme gelen riske dayalı ve faizsiz Venture Capital Sisteminin kaynağı olarak da değerlendirilen commenda iş ortaklık türünün, İslamî mudârebe ortaklığı ile bir benzerliğe sahip olduğuna yönelik yaygın bir görüş vard ${ }^{18}$ (Kumaş, 2006: 370-371). Şekilden de görülebileceği üzere Batı Avrupa kurumları aynı amaçları gerçekleştirmek için kullanmaya başladığı zamanlarda vakıf, İslam’ın sosyal hizmetler sağlamak için ana örgütsel biçimi haline geldi. Örgütsel boşluk, Batı'nın kurumsal örgüt biçimini kâr odaklı üretime, finansa ve ticarete uygulamaya başlamasıyla XVI. yüzyılın sonunda daha da genişledi. XIX. yüzyıl Fransa'sında ortaklıklar en yaygın örgütsel biçim olmaya devam etti, ancak istihdam veya sermaye ile ölçülen işletme ne kadar büyükse, kurumsal özelliklere sahip olma olasılı̆̆ı da o kadar yüksek oluyordu (Kuran, 2005: 802811). Osmanlı Devleti'nde para vakıflarının ${ }^{19}$ ortaya çıkışıyla toplum yeni bir finansman yöntemiyle tanışmıştı. Bir nevi kredi müessesesi ${ }^{20}$ olan para vakıfları, ailesinin ihtiyacını karşılamakta zorlanan kişilerin, küçük ve orta ölçekte faaliyet gösteren esnaf ve girişimcinin finansman talebini karşılamaktaydı (Döndüren, 2008). İş ortaklıkları ve para vakıfları arasındaki ilişkiye baktığımız zaman vakıflar binlerce kişinin değil tek bir kişinin tasarruflarına sahip olduğu için girişimcilere kullandırabilecekleri sermaye görece küçüktü. Çoğu zaman borç alan kişiler bu parayla var olan işlerini büyütmek ya da yeni işler kurmak yerine İstanbul'daki sarraflara daha yüksek faizle borç veriyorlardı. Bu nedenle başlangıçta ümit verici ve özgün bir Osmanlı sermaye kurumu olarak ortaya çıkan para vakıflarının,

17 İlk kez X. veya XI. yüzyıllarda İtalya'da ortaya çılkan commenda Ortaçağda Akdeniz ticaretinin gelişmesinde önemli bir rol oynamıştı. Özellikle sermayenin toplanması, denizaşırı ticari faaliyetler ve işletmeci ile yatırımcının bir araya getirilmesi gibi sorunların aşılmasında başvurulan en önemli ortakllk türüydü. Bkz. Udovitch, 1962.

18 X. yüzylldan itibaren mudarebe ortaklı yöntemi commenda adı ile Avrupa 'ya geçmiş, Avrupa ticaret hukukunda diğer ortaklık çeşitlerine de öncülü̈k etmiş ve XX. Yüzylla gelindiğinde emek-sermaye ortaklığının en önemli halkası olarak risk sermayesi ile tamamlanmıştı. Bkz. Döndüren, 2008.

19 Para vakıfları, Allah adına insanlığa hizmet etmek amacını güden ve kuruluş sermayesi paradan oluşan vakıf fonlarıydı. XVI. yüzyllın sonlarında para vakıfları bütün Anadolu'da ve devletin Avrupa'daki eyaletlerinde yayginlaşmış̧t. Dini amaçlarla belirli miktarda nakit parayı dağıtmak isteyen varlıklı kişiler tarafindan kurulan para vakıflarında vakfin sermayesi ilk olarak borç almak isteyenlere aktarllyyor, onlar da belirli bir süreden sonra vakfa anapara ile birlikten "fazladan" bir parayı geri ödüyorlardl. Bu "fazla" sonrasinda sosyal ve dini amaçlar için kullanıliyordu. Bkz. Çizakça, $1999 b$.

20 Para vakıflarının bir kredi kurumu olup adeta bir banka gibi çalıştı̆̆ ancak yapısal olarak bankadan farklı olduğu yönündeki geniş bir değerlendirme için bkz. Çizakça, $1999 \mathrm{~b}$. 
Kaya, P.H. (2021), “Âdem-i Merkeziyetçilik-Merkeziyetçilik Tartışmaları Bağlamında Osmanlı Devleti ve Fransa'da Savaşlar, Mali Baskılar, Kurumsal Değişim”, Sosyoekonomi, 29(50), 433-463.

aslında sermaye dağıtım kurumu oldukları görüldü. Vakıflardan krediyi alanların çoğu küçük tüketici, esnaf ya da girişimciydi ve vakıfların yarattıkları fonlar önemli girişimleri finanse etmekte kullanılmıyordu. Acaba talep yönünden neden bir sermaye birikimi oluşmadı ya da girişimci neden çok sayıda vakıftan kredi alma yolunu seçmedi? Para vakıfları borç alan kişiden teminat olarak evini rehin göstermesini istiyordu. Para vakıflarının ödünç para karşılığında bu kadar büyük bir teminat istemeleri etkin sermaye birikim araçlarına dönüşememelerine neden olmuştu. Bir kişi aynı anda birden çok para vakfından kredi almak isterse rehin olarak birçok ev göstermek zorundaydı (Çizakça, 1999b: 115-118). Bu nedenle Osmanlı Devleti'nde böyle büyük bir sermayeyi bir araya getirerek bir şirket oluşturma o dönemlerde kolay değildi.

Tüm bu yaşananlar, XVII. yüzyılın son döneminde ve XVIII. yüzyıl boyunca Fransa'da sermaye sahiplerinin Kralın hareketlerini kısıtlayarak kralı, Osmanlı padişahlarının izlediği kademeli reformlardan ziyade temel kurumsal reform yapmaya yönlendirdi.

1690'larda Osmanlı Devleti mali sistemi, Fransa'nın General Farms Şirketi aracılığıyla iltizamların toplanmasında merkezileşme hamlesine karşılık daha fazla âdem-i merkeziyetçilik ve mali sözleşmelerde daha az güvenlik yönünde, Fransa'nın tersi yönde ilerledi. Bu doğrultuda Osmanlı Devleti'nde temel reformlar yerine kademeli reformlara devam edilmiş ve XVII. yüzyılın sonunda artan nakit ihtiyacına çözüm olarak iltizam sisteminden malikâne sistemine geçilmişti. İltizam sisteminin ardından, ortaya çıkan malikâne sistemi de yine aynı amaca hizmet etmiş ve bu defa belirli bir süre için verilen iltizamların içeriği değişerek kayd-ı hayat şartıyla verilmeye başlamıştı. Osmanlı Devleti mülk anlayışının değişmesinin ve özel mülkiyetin ortaya çıkmasının asıl nedeni olarak görülen malikâne sistemi ile idari, ekonomik ve toplumsal alanda değişimler yaşanmıştı. XVI ve XVII. yüzyılların nakit ihtiyacını karşılamanın yöntemi iltizam gibi görünse de XVIII. yüzyılda mukataaların malikâneye dönüştürülmesine izin verilmişti (Tabakoğlu, 1985a: 130). Malikâne sisteminde muaccele ve müeccele adı verilen iki farklı ödeme şekli ile mukataaların gelirleri satışa çıkarılmıştı. Muaccele; satış sırasında ödenen peşin miktar iken müeccele her yıl ödenecek taksitti. Yani; malikâne sistemi, devletin nakit ihtiyacını hem satışta hem de her yılbaşında taksit olarak almasını sağlayarak nakdi gelirleri artıracak açık artırma usulüyle satışı gerçekleştirilen bir sistem olarak ortaya çıkmıştı (Genç, 2009: 107). Osmanlı Devleti'nde mali sistem içinde General Farms Şirketi'ne benzeyen hiçbir kısıtlayıcı örgüt oluşmadı. Malikâne uygulamasının başladığı 1695 yılı ile 1697 yılı arasında toplamda 1113 malikâne satışı gerçekleşmiştir. Bu sayı içerisinde biri Yahudi dördü Hıristiyan olmak üzere 5 tane gayrimüslim malikâneci bulunmaktaydı. Ayrıca aynı dönemde malikâne sahiplerinin \%19'u İstanbul'da yaşamakta ve bunların yatırdıkları muaccele bedelleri \%42 idi (Özvar, 2003: 77-79).

Malikâne sisteminde devletin hem satış bedeli üzerinden para alması hem de sonrasında yıllık müeccelelerini alması merkezi hazinenin nakit sıkıntısına ilk zamanlarda 
çare oluyordu. Bu kârlı sistem, ayrıca cebelü bedeliyesi ${ }^{21}$ adı altında da bir takım ödemeler alarak, her yönüyle bir kâr ve nakit karşılama yöntemine dönüşmüştü. İran savaşları sırasında, 1738'de, ek bir mali kaynak sağlama amacıyla 1000 müeccelelerin her 1000 guruşundan 150 guruş alınmıştı (Tabakoğlu, 1985a: 134). Ayrıca, XVIII. yüzyılda alınan vergilerden biri de her padişahın tahta çıkması ile birlikte, müeccele miktarlarının \%25'i kadar olan "cülûs resmî"22 idi (Genç, 2009: 116). XVIII. yüzyılda mukataaların eyalet boyutunda verilmesi mâlikane sisteminin ne kadar yaygınlaştığının bir göstergesiydi. Öyle ki 1746 yılında Adana, Trablusşam eyaletleri, Rakka eyaleti, Kıbrıs ve Mora Muhassıllıkları ve Aydın muhassıllığı mâlikane olarak verilmişti (Tabakoğlu, 1985a: 135).

\section{Grafik: 4}

\section{Yıllık Muaccele Gelirleri (Ortalama-Kuruş)}

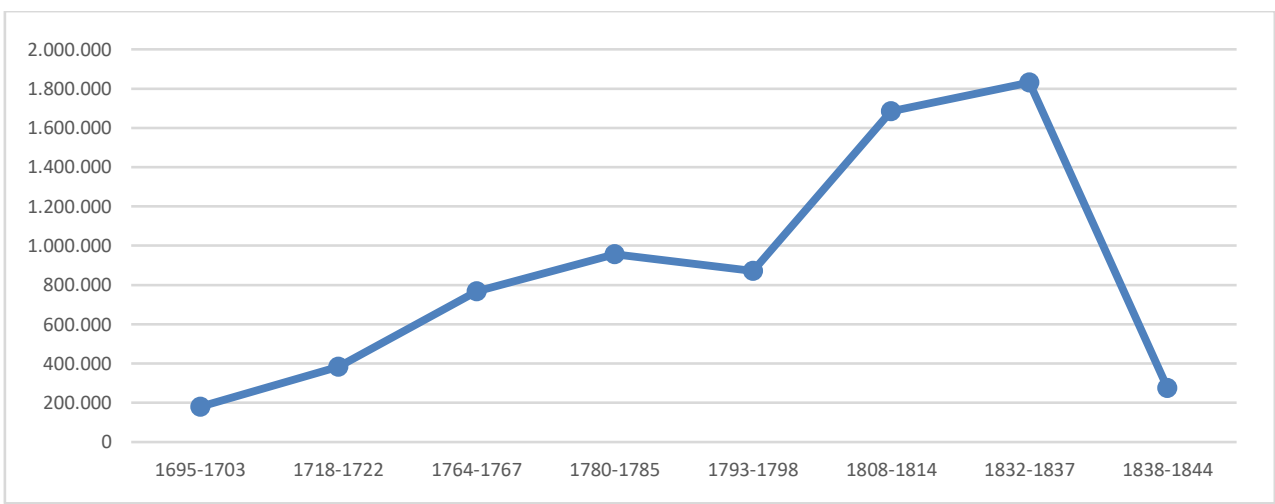

Kaynak: Genç, 2009: 117.

Fransa'daki iltizamcıların XVIII. yüzyıl boyunca mülkiyet haklarının güvenliğini artırma becerilerinin aksine, Osmanlı Devleti'nde malikâne sistemi kapsamındaki mali sözleşmeler güvenli olmaktan çok uzaktı1². Mukataaları iltizama alan malikâneciler genellikle İstanbul'da yaşıyordu ve mukataalarını gayri resmi olarak başkalarına iltizama veriyorlardı. Hatta bazı mukataalarda ikinci ve üçüncü elden iltizamlar bile vardı. Böylece

21 Silâh, zırh" anlamina gelen Moğolca cebe kelimesinden türetilen cebelü (cebeli) "zırhll, teçhizatl asker" demekti. Cebelü asker, tımar sahibinin (sipahi) geliriyle doğrudan bağlantıllydı ve saylları bu gelirlere göre tespit edilmişti. Sipahiler gelirleri karşıllığı cebelü çıkartmazlarsa, kendilerinden cebelü bedeliyesi adı altında vergi talep edilirdi. XVII ve XVIII. yüzylllarda cebelü bedeliyesi uygulaması hazinenin paraya olan ihtiyacı sebebiyle yaygınlaştırılmış̧t. Bununla birlikte yeni savaş tekniklerinin ortaya çıkması ve tımar sisteminin giderek bozulması sonucu bu askerî teșkilât zamanla önemini yitirmişti. Bkz. Emecen, 1993. Padişah değişikliklerinde askerlere ödenen bahşişlere "cülus" denilmekteydi.

23 Malikâneciyi bu derece büyük bir risk almaya yönlendiren şey neydi? Çizakça'ya göre bu sorunun cevabı "mülkiyet hakları" kavraminda gizli olabilirdi. Askeri bir sinıfin bir üyesi Osmanlı Devleti tarihinde ilk defa yaşamı boyunca özel mülkiyete benzer bir mülkiyete sahip olabiliyordu. Muacceleyi peşin olarak ödeyen ve ylllı ödemeleri de düzenli olarak yapan bir malikâneci kontrol ettiği vergi kaynağından tümüyle yararlanabiliyordu. Malikâneci risk alan bir girişimciydi; hayatının geri kalan kısmında devlete ödediği toplam miktarın üzerinde gelir elde edebiliyorsa kâr ediyor, aksi takdirde zarara giriyordu. Bkz. Çizakça, $1999 b$. 
Kaya, P.H. (2021), “Âdem-i Merkeziyetçilik-Merkeziyetçilik Tartışmaları Bağlamında Osmanlı Devleti ve Fransa'da Savaşlar, Mali Baskılar, Kurumsal Değişim”, Sosyoekonomi, 29(50), 433-463.

iltizam sisteminde olduğu gibi bir malikâneci hiyerarşisi ortaya çıkmıştı (Batmaz, 1996: 42). Ne yazık ki malikâne sistemi XVIII. yüzyılda devletin olumlu beklentilerini karşılayamadı. Malikâneciler öldüğünde kontratlarının tekrar devlet denetimine dönmesi sağlanamadığı için bu sistem devlete ulaşan vergi gelirlerini artırmak yerine tersine azalttı (Pamuk, 2013: 138). Özellikle 1683 yılından sonra merkezi otoritenin zayıflaması sonucu ortaya çıkan iç güvensizlik ortamı ayânların ${ }^{24}$ doğmasına neden olmuş ve XVIII. yüzyıl boyunca ayân ailelerin taşradaki gücü günden güne artmıştı. Bu aileler, idari ve askeri görevliler, hakimler, din bilginleri ve yerel tüccarlar arasından yükseldi. XVIII. yüzyılda, merkezi idare ayrıca ayânlara kamu düzenini koruma görevini vermiş ve onlardan gelirleriyle birlikte savaşlara katılmalarını istemişti (Pamuk, 2014: 9). 1768 Osmanlı-Rus Savaşı'nda devletin askere ve paraya olan ihtiyacından dolayı taşra idaresini ele geçiren ayânlardan yardım istemesi, ayânlar üzerindeki devlet kontrolünün zayıflamasına ve ayânların idari, iktisadi ve sosyal açıdan güçlerini artırmasına neden olmuştu (Özdeğer, 2000: 78). Öyle ki, Anadolu ve Rumeli'de her vilayet ya da sancakta yavaş yavaş ayânlar arasında büyüklerinden, küçüklerine doğu uyruklaşmanın geliştiği görülmüş, böylece Osmanlı Devleti hükümet düzeni yerel idaresi yönünden merkeziyetçiliğin düşmanı bir karakter kazanmıştı (Akdağ,1974: 53). XVIII. yüzyıl devletin ayânlarla uzlaşma eğilimlerine ve mücadelelerine ve kendini âdem-i merkeziyetçi eğilimden kurtarma çabalarına sahne olmuştu (Sofracı \& Ergenoğlu, 2016: 389). Malikânecilerin sözleşmelerini düzenleyen kanunlara aldırış etmemesi ayânlıkla beraber daha da kötüleşince merkezi hükümet, müsâdere ${ }^{25}$ usulünü kullanmış, iltizamlara el koymaya ve yerel güçleri uzaklaştırmaya başlamıştı.

Osmanlı Devleti'nde malikâne sistemindeki mültezimler XVII. yüzyılın sonundan itibaren, hiçbir zaman Fransız iltizamcılar ile aynı ölçekte sermaye bir araya getiremediler. İstanbul'dan gelen ortakların ve yatırımların sayısı 1768'de 711 iken 1789'da 963'e yükselmişti. İstanbul'dan malikâne sistemine katılan yatırımcıların toplam payı ise aynı tarihlerde \%65'ten \%87'ye çıkmıştı (Salzmann, 2004: 148-150). Taşra ve merkezi otorite arasında yaşanan bu iktidar mücadelesinde güçlü taraf İstanbul'un seçkinleri olmuştu. Çünkü halkı vergilendirirken aynı zamanda onları koruyabilecek olanlar kendilerine göre ancak İstanbul'un seçkinleri idi (Faroqhi, 1994: 691-692). 1787-88 yıllarında aktif varlıkları 100 bin kuruşun üstünde olan 14 aile vardı ve bu aileler İstanbul'da bulunan yatırımcılar içinde \%2'yi oluştururken, yatırım hacminde \%30'un üstünde paya sahiptiler. Tüm bunlardan hareketle İstanbul'dan gelen yatırımlar içerisinde de belirli bir zümrenin daha da öncelikli olduğunu söylemek yanlış olmazdı (Salzmann, 2004: 108). Fransa'da ise tam tersine 1788 yılında iltizam sistemi ile ilişkili sermayenin hemen hemen tamamını 16 kişi

24 Aslinda XVI. ve XVII. yüzylllarda ayân tabiriyle taşrada servet ve nüfuz sahibi kimseler kastedilmekteydi. Kapıkulları, yeniçeri serdarları, sipahiler, eminler, eski beylerbeyleri, sancakbeyleri, kadılar, mültezimler, müderrisler gibi zümreler ayânın kaynăğıı oluşturuyordu. Bkz. Tabakoğlu, 1985a.

25

Müsâdere, devlet adamlarının hayatları boyunca elde ettikleri malların şahsa değil makama ait oldukları düşünülerek, vefatlarının ardından çocuklarına yetecek kadar mal bırakilip geri kalan miktara el konulmasıydl. Osmanlı'nın Kuruluş döneminde pek başvurulmayan müsâdere usulüne Fatih Sultan Mehmed döneminde merkezi yönetimin gücünün tescillenmesi adına daha sık başvurulmuş, XVII. yüzyıla gelindiğinde de gelir sağlama amacıyla sık sık uygulanmıştır. XVIII. yüzyılın sonlarında artık sadece devlet adamlarının değil siradan insanların mal varlıklarına da müsâdere uygulanmaya başlanmıșt. Bkz. Öğ̈̈n, 2006. 
Kaya, P.H. (2021), “Âdem-i Merkeziyetçilik-Merkeziyetçilik Tartışmaları Bağlamında Osmanlı

Devleti ve Fransa'da Savaşlar, Mali Baskılar, Kurumsal Değişim”, Sosyoekonomi, 29(50), 433-463.

kontrol ediyordu. Büyüklü küçüklü Osmanlı yatırımcıları, sürekli olarak iltizamlar arasında çeşitlenmeyi seçti ${ }^{26}$. Böylelikle General Farms Şirketi, XVIII. yüzyılda krala karşı kısıtlamalar getirmek için yeterli sermayeyi bir araya getirirken, bu kritik kitleye bir Osmanlı iltizam çiftliği hiçbir zaman ulaşamadı (Balla \& Johnson, 2009: 836).

XVIII. yüzyılın sonunda Fransa'da gerçekleştirilen temel kurumsal reformların aksine, Osmanlı padişahları kademeli reformlarla XIX. yüzyıla kadar devam ettiler. 17681774 Osmanlı-Rus Savaşı sonrası imzalanan Küçük Kaynarca Antlaşması'nın savaş tazminatını ödeyebilmek için birçok büyük iltizam tesisini devraldı ve bunları esham ${ }^{27}$ sistemi ile işleterek devlete ek mali kaynak sağladı. Esham sistemi ile iç borçlanma süreci başlatılmış ve ilk olarak 1775 yılında İstanbul Tütün Gümrüğü mukataasına uygulanmıştı. $\mathrm{Bu}$ yöntemle devlet elindeki mukataaları çok sayıda paya bölmüş ve her paya düşen yıllık vergi gelirinin faiz denilen bir bölümünü ömür boyunca ve peşin olarak ödenen bir bedel karşılığında özel kişilere satmıştı (Öner, 2005: 164).

\section{Vergi Yönetimi ve Merkezileşme Çabaları}

XVIII. yüzyıl boyunca Fransız hükümeti taille, capitation, dixieme-vingtieme gibi dolaysız vergileri rüşvet alan kraliyet görevlileri; dolaylı vergileri ise altı yıllık sözleşmeler ile General Farms Şirketi aracılığıyla topladı. Yüzyıllar içerisinde iltizam sistemi yavaş gelişti ve Colbert, 1681 yılında büyük çiftlikleri geçici olarak birleştirmeyi başardı. Colbert'ın, XVII. yüzyılın sonlarında General Farms Şirketi ile konsolidasyon sürecini yeniden başlatması merkezileşmeye doğru bir dönüm noktasıydı. 1768 yılına gelindiğinde General Farms Şirketi toplam devlet gelirinin yaklaşık \%45'ini topluyordu. Fransız yöneticiler, bir grup özel personelin devlet gelirinin böylesine büyük bir yüzdesini kontrol etmesine izin vermenin sonuçlarından korkmaya başladılar. Dahası, iltizamcılar devlet tarafından kullanılandan daha iyi bir muhasebe sistemi, katı bir hiyerarşi, ayrıntılı personel kayıtları gibi verimliliği artıran birçok yeni teknik geliştirdi (Matthews, 1958: 218).

Devrim, dolaylı vergilerin özelden kamusal tahsiline geçiş için gerekli bir koşul muydu? Bu yöndeki önemli reformlar Devrim'den neredeyse on yıl önce meydana geldiğinden, yanıt hayır gibi görünüyordu. 1777 yılından başlayarak 1780 yılına kadar dönemin Maliye Bakanı Jacques Necker, Fransız idari sisteminde önemli reformlar başlattı. $\mathrm{Bu}$ reformların en önemlileri; genel olarak yereldeki memurların gücünü azaltarak dolaysız vergilerin kontrolünü merkezileştirme ve bürokratikleştirme girişimi ve dolaylı vergilerin yaklaşık \%40’ını General Farms Şirketinin kontrolünden alarak bunları kamu idaresine

26 Örneğin, Ístanbul'daki Tütün Gümrük (Tobacco Customs) iltizamı 1707 ile 1737 arasında dört mültezime sahipti, ancak 1759'da 22 sahibi vardl ve en küçük pay 1/128 idi Bkz. Özvar, 2003.

27 Esham "pay, hisse” anlamına gelen sehm kelimesinin çoğuludur. Osmanlı Devleti maliye teşkilatında ilk defa, 1775 yılında uygulamaya konularak 1860'll yıllara kadar devam eden bir iç borçlanma sistemini ifade eder. Bu sistem şu şekilde işlemekteydi: Mukataa olarak bilinen vergi birimlerine ait yıllık nakdî gelirlerin, faiz denilen belirli bölümlerinin sehimler halinde parçalanarak özel şahislara "muaccele” adı verilen bir peşin meblă̆ karşılığında kayd-ı hayat şartı ile satılmasıdır. Satışa sunulan, bir mukataaya ait yıllık nakdî gelirin tamamı değil sadece faiz denilen belirli bir bölümüdür. Bkz. Genç, 1995. 
Kaya, P.H. (2021), “Âdem-i Merkeziyetçilik-Merkeziyetçilik Tartışmaları Bağlamında Osmanlı Devleti ve Fransa'da Savaşlar, Mali Baskılar, Kurumsal Değişim”, Sosyoekonomi, 29(50), 433-463.

devretmekti (Doyle, 1996: 65-70). Dolaysız vergileri toplayan rüşvet alan memurların reformları sürekli engellemeye çalışmasına rağmen dolaylı vergilendirmede iltizamcılar devletle olan sözleşmeleri birkaç yılda bir yenilendiği için reformların gerçekleştirmesine olanak sağlıyorlardı. 1777-1780 döneminde aides ler ve damga vergileri iltizamcıların kontrolünden çıkarıldı ve 1791 yılına kadar devlet kontrollü bir rejim hâkim oldu. Dolaylı vergiler zaten merkezileştirilmiş ve kısmen bürokratikleştirilmişti; üçüncü adım, onları özelden kamu eline geçirmekti. 48 iltizamcı bastırıldı ve onların topladığı gelirler merkezi hazineye aktarıldı. Reform hem rüşveti azalttı hem de merkezileşmeyi artırdı. Ancak Necker devrilince bir yıl içinde her şey tersine döndü. Dolaysız vergilerin rüşvet alan yöneticilerinin yerinden edilemeyecek kadar güçlü olduğu ortaya çıktı. Bu durumda, köklü güçlerini kırmak ve en yüksek düzeydeki doğrudan vergi idaresini nihai olarak merkezileştirmek ve bürokratikleştirmek için bir devrim gerekecekti (Kiser \& Kane, 2001: 204-205).

Tablo: 2

\section{Fransız Vergi İdaresi Tarihinde Önemli Olaylar}

\begin{tabular}{|l|l|}
\hline Yllar & Olaylar \\
\hline 1600 öncesi & Merkeziyetçi Bir Yapı \\
\hline 1600 & Âdem-i Merkeziyetçi Bir Vergi Sistemi \\
\hline 1681 & General Farms Şirketinin Kurulması \\
\hline 1723 & İltizam Sistemiyle Dolaylı Vergilerin Merkezileştirilmesi \\
\hline $1780-1800$ & İletişim / Ulaşım Alanında (Hızında) Yaşanan Önemli Gelişmeler \\
\hline 1780 & Aides ve Damga Vergilerinin İltizam Sistemi ile Toplanmasının Sonlandırılması \\
\hline 1789 & Fransı Devriminin Başlaması-İltizamın Sonu \\
\hline $1792-1799$ & Merkezi Yönetimin Kısmen Bürokratikleşmesi \\
\hline $1799-1800$ & Merkezileştirme: Valilerin Ortaya Çıkışı \\
\hline $1815-1830$ & Yeniden Monarşi-Restorasyon Devri \\
\hline $1830-1850$ & Yerel Yollar da Dahil Olmak Üzere Yol Yapımında Önemli Artış \\
\hline 1870 & Merkezi Yönetimin Bürokratikleşmesi \\
\hline $1870-1898$ & Dolaylı Vergilerin Bürokratikleşmesi \\
\hline 1914 & Doğrudan Vergilerin Bürokratikleşmesi ve Merkezileşmesi: Gelir Vergisi \\
\hline
\end{tabular}

Kaynak: Kiser \& Kane, 2001: 190.

4 Ağustos 1789 gecesi, Ulusal Meclisin nesiller boyu Fransız yaşamını şekillendiren birçok gelenek ve kurumu kaldırdığı ve radikal kararların alındığı bir gece olarak bilinmektedir (Doyle, 1996). Çoğu bilim insanı Fransız Devrimi’ni, Fransız devletinin merkeziyetçilik ve bürokratikleşmesinde dönüm noktası olarak görür (Skocpol, 1979; Tilly, 1990; White, 2001). 1789'dan önce merkezi bürokratik yönetime doğru önemli hareketler vard1, ancak bunlar dolaylı vergiler alanıyla sınırlıydı. Dolaysız vergi idaresinin çoğu da dahil olmak üzere Fransız devletinin diğer kısımları, Devrimden sonraki yüzyılda âdem-i merkeziyetçi yapısına devam etti. Acaba Fransa'da vergi yönetiminin merkezileşmesi ile Fransız Devrimi arasında ilişki var mıydı? Devrim, ancak devletlerin izleme kapasitesi (yöneticilerin görevlilerin eylemleri hakkında bilgi toplama yeteneği), iltizam ve yerel eşraflar tarafından tahsilat gibi alternatiflerden merkezi örgütlenmeyi daha verimli hale getirecek kadar geliştirildiğinde bürokratikleşmeye ve merkezileşmeye yol açardı. İzleme kapasitesi, vergi türlerine ve yönetim düzeylerine göre değişiklik gösterdiğinden, eyaletler de farklı hızlarda bürokratikleşir ve devrimden farklı şekilde etkilenirdi. Bu, Fransa'daki devrimin neden dolaylı vergiler üzerinde dolaysız vergilere göre daha fazla etkiye sahip olduğunu açıklıyordu. Dolayısıyla devrim bürokratikleşme ve merkezileşme için ne gerekli ne de yeterli bir koşuldu, ancak reformun önündeki engelleri ortadan kaldırarak sürece 
katkıda bulundu (Weber, 2012; Tilly, 1990) ${ }^{28}$. Bu çalışmanın odak noktası, bürokratikleşmenin diğer yönlerine değil, esas olarak merkezileşmesi üzerinedir.

Fransa'da tüketim ve alım-satım işlemlerinden alınan dolaylı vergiler, belli bazı vergiler için çok kısa dönemler hariç genel olarak XIII. yüzyıldan Fransız Devrimi'ne kadar iltizam sistemi ile toplanmaktaydı. Doğrudan vergiler ise XIII. yüzyılda ve yalnızca 16431661 arasında iltizama verilirken, bu dönemler dışında merkezi devlet idaresi tarafından belirlenmiş götürü verginin bir karışımı ile toplandı. 1681'den önce dolaylı vergiler âdem-i merkeziyetçi bir yapıda toplanıyordu. 1681'de General Farms Şirketi'nin kurulması ile iltizam sistemi merkezi hale getirildi ve hemen hemen tüm dolaylı vergiler bu şirket çatısı altında birleştirildi (Buluş, 2010: 89-90).

Tablo: 3

Osmanlı Devleti Vergi İdaresinde Yaşanan Önemli Olaylar*29

\begin{tabular}{|l|l|}
\hline Yıllar & Olaylar \\
\hline XVI. Yüzyıl Öncesi & Tımar Sistemi ve Merkeziyetçi Bir Yap1 \\
\hline XVI. Yüzyıl & İltizam Sistemi ve Nispeten Âdem-i Merkeziyetçi Bir Yap1 \\
\hline $1600-1695$ & İltizam Sistemi ve Âdem-i Merkeziyetçi Bir Vergi Sistemi \\
\hline 1695 & İltizam Sisteminden Malikâne Sistemine Geçiş \\
\hline 1700 Sonrası Dönem & Ayânlığın Ortaya Çıkıșı ve Vergilerin Âdem-i Merkeziyetçi Bir Yapıda Tahsisi \\
\hline $1800-1839$ & III. Selim ve Sonrasında II. Mahmud ile Merkezileşmeye Yönelik Adımlar- Vergi Otoritesinin Merkezileştirilme Çabaları \\
\hline 1839 & Tanzimat Fermanı- Merkezi Otoritenin Güçlendirilmesi \\
\hline 1840 & Muhassıllık Teşkilatının Kurulması- Vergi Otoritesinin Merkezileştirilmesi \\
\hline 1842 & Muhassıllık Teşkilatının Kaldırılması ve İltizam Sistemine Dönüş \\
\hline 1864 & Vilayet Nizamnamesi ve Âdem-i Merkeziyetçiliğe Kayış \\
\hline 1878 & I. Meşrutiyetin Bitişi ve Merkeziyetçiliğin Güçlenmesi \\
\hline
\end{tabular}

*Yazar tarafindan oluşturulmuştur.

1789 Devrimi Fransa için önemli bir dönüm noktasıydı. 1789’da Fransa’nın verimsiz, etkisiz, nefret edilen vergi sistemi monarşiyle birlikte yıkıldı, ancak tamamen ortadan kaldırılması için daha fazla zamana ihtiyaç vardı (Chanel, 2015: 79). Tablodan da görebileceği üzere 1780-1800 döneminde iletişim ve ulaşım alanında önemli gelişmeler yaşandı. $\mathrm{Bu}$ gelişmeler yavaş yavaş merkezileşmenin önündeki engelleri kaldırsa da merkezileşme farklı vergi türleri için farklı zamanlarda meydana gelmişti. Bu anlamda

28 Max Weber'in ufuk açıcı çalışmasından (2012) başlayarak, sosyologlar ve tarihçiler siyasi kurumların bürokratikleşmesinin nedenlerini tartıştılar. En yaygın argümanlardan biri, devrimin bürokratikleşmeyi kolaylaştırdığıdır. Vergi idaresi, bu ve diğer erken modern devletlerde sivil devlet aygıtının açık arayla en büyük parçası olduğundan, bürokrasinin oluşumunu incelemek için uygun bir yerdi. Bkz. Tilly, 1975; Weber, 2012.

Osmanlı Devleti'ndeki hem merkeziyetçi hem de âdem-i merkeziyetçi uygulamalarl eyaletler ve taşra yönetimi ile ilgili bazı nitelikler oluşturmaktaydı. Osmanlı devleti, idari bakımdan merkeziyetçi bir yapıya sahip olmakla birlikte, eyaletler arasında yönetim biçimleri bakımından bazı farklılıklar söz konusuydu. Bu farklılıkların en önemlisi, birçok Osmanlı eyaletinin has ve bazılarının ise salyane ile idare edilmesiydi. Coğrafi bakımdan has ile idare edilen eyaletler, daha çok imparatorluğun iç kesimlerinde ve Anadolu ile Rumeli topraklarında yer almaktayd. Salyane ile idare edilenler Cezayir, Tunus gibi Osmanlının büyük askeri harekatlarının dişında kalan uç bölgelerdi. Salyane ile idare edilen eyaletlerde, has ile idare edilenlerdeki gibi tımar sistemi mevcut değildi. Osmanlı'da bir eyaletin başka bir eyalete, belki bir sancă̆ın başka bir sancă̆a benzemez niteliği o dönemin özellikleri açısından gerekli sıkı bir merkeziyetçiliğin yanında âdem-i merkeziyetçi uygulamaların da var olabilmesini mümkün kılan önemli bir etkendi. Bunun ekonomik, askeri sosyal, kültürel, dini ve siyasi-idari birçok yönü bulunmaktaydl. Bkz. Ökmen \& Yllmaz, 2015. 
Kaya, P.H. (2021), “Âdem-i Merkeziyetçilik-Merkeziyetçilik Tartışmaları Bağlamında Osmanlı Devleti ve Fransa'da Savaşlar, Mali Baskılar, Kurumsal Değişim”, Sosyoekonomi, 29(50), 433-463.

Osmanlı Devleti ve Fransa'daki merkezileşmenin boyutları kendi tarihsel olayları bağlamında değerlendirilecektir.

Tarihte devletlerin önce merkeziyetçilikle idare olunduğu, sonra âdem-i merkeziyetçi bir yapıya büründüğü, ardından tekrar merkeziyetçi yapıya döndüğü görülmektedir. Osmanlı Devleti'nde âdem-i merkeziyetçi ve merkeziyetçi yapı hep iç içe olmuştu. Osmanlı Devleti'nin mali-idari sistemi merkeziyetçiliğe karşı değil aksine merkeziyetçiliğin içerisinde yer alıyordu. XVI. yüzyıla kadar taşra idaresinin temelini tımar sistemi oluşturuyordu. Beylerbeyiler ve sancakbeyleri bölgelerinin mülki ve askeri önderleriydiler. Sefere çıkıldığında tımarlı sipahilerle onların cebelüleri sancakbeylerinin emrinde toplanır ve hepsi beylerbeyinin emrinde sefere katılırlardı. Fakat tımar sistemi bozulunca cebelü yetiştirmek önemini kaybettiği gibi mahallelerinde bir denge unsuru ve merkezin temsilcisi olan tımarlı sipahiler de artık şehirlerde rızık peşinde koşmaya başlamıştı (Tabakoğlu, 1985a: 222). Mali bunalımın kendini hissettirdiği XVI. yüzyılın ikinci yarısında, kamu harcamalarının giderek artması sonucunda, Osmanlı Devleti’nin tarım ve toprak rejimi olan tımar sistemi de olumsuz etkilenmişti. Vergi gelirlerini tımar düzeni çerçevesinde dolaylı olarak kullanmak yerine dolaysız olarak merkezi hazinede toplama çabaları daha önce de bahsedildiği gibi iltizam sistemini doğurmuştu. İltizam sistemi ile birlikte vergilerin âdem-i merkeziyetçi bir yapıda toplanması söz konusu olmuştu. Ancak bu yapı merkeziyetçilikten kopuk değildi. Sonuçta iltizam sistemi içerisinde de olsa vergiler devlet adına toplanmaktaydı. İltizam sisteminde devlet her ne kadar vergilerin tahsilatını kişilere emanet etse de nispeten merkezi olmayan bu sistemi aşırı tahsilat, izinsiz kazanç, zimmete para geçirme ve zulüm gibi durumlardan korumak için mültezimlerin etrafını denetmenler ve muhafızlarla çevirmişti (Sofracı \& Ergenoğlu, 2016: 387).

XVIII. yüzyıl boyunca girilen ve kaybedilen savaşlar Osmanlı Devleti'ni mali bunalıma sürüklemiş, devlet nakit ihtiyacını gidermek için iltizam sisteminden malikâne sistemine geçmişti. Bu süreçte ayânların ortaya çıkışı âdem-i merkeziyetçi yapının sürdürülmesine neden olmuştu. XVIII. yüzyılın sonlarında III. Selim ile başlayan (17891807) ve sonrasında II. Mahmud (1808-1839) ile devam eden yenileşme sürecinin temelini mali anlamda âdem-i merkeziyetçilikten merkeziyetçiliğe doğru dönüşüm sağlayarak merkezi devletin gücünü artırmak oluşturmaktaydı. Tanzimat döneminde (1839-1876) istenilen merkezileşme hareketinin iki önemli nedeni bulunmaktaydı. Bunlardan birincisi Fransa' da Fransız Devrimi ile halkın dolaylı vergilerin toplanmasında lanetledikleri iltizam sistemini kaldırarak halkın bir nebze de olsa rahatlamasının sağlanması gibi Tanzimat reformu ile de merkezileşme reformları ile halkın yerel toprak sahipleri tarafından yıpratılmasını durdurmaktı. İkincisi de yerelde toplanan gelirlerin doğrudan merkezi hazineye aktarılması yoluyla gelirlerin artırılması çabasıydı (Weiker, 1968: 464-465). Osmanlı Devleti mali ve siyasi merkezileşmesinde resmî kurumlar sınırlı bir rol oynadı. Osmanlı parlamentosu, 1876-77 arasındaki kısa bir dönem hariç, 1908 Jön Türk devriminin sonrasına kadar kurulmamıştı. Kurumsal değişikliklerin zamanlaması ve gelir rakamları, Osmanlı Devleti mali konsolidasyonunun öncelikle modern askeri tekniklerin ve idari organizasyon tarzlarının ve vergi toplama sürecinde aracıların büyük paylarının azalmasına 
Kaya, P.H. (2021), “Âdem-i Merkeziyetçilik-Merkeziyetçilik Tartışmaları Bağlamında Osmanlı

Devleti ve Fransa'da Savaşlar, Mali Baskılar, Kurumsal Değişim”, Sosyoekonomi, 29(50), 433-463.

yardımcı olan demiryolları gibi diğer yeni teknolojilerin benimsenmesiyle sağlandığını göstermekteydi (Pamuk, 2014: 5).

Fransız Devrimi ile beraber vergi sisteminde önemli gelişmeler yaşanmıştı. Bunlardan ilki, vergi sisteminin büyük bir bölümünü kontrol eden iltizam sisteminin kaldırılmasıydı. Doğrudan vergi tahsilatı, Devrim'den sonra oldukça âdem-i merkeziyetçi idi. 1790 ve 1791 yılları arasında, aides, traites, octrois, gabelle ve tabac bir dizi başka vergi ve harçla birlikte kaldırıldı, ancak bazıları -özellikle gabelle ve octroi- kısa süre sonra eski durumuna getirildi ve sonra tekrar yürürlükten kaldırıldı. 1789 ile 1793 yılları arasında eski dolaysız vergiler, kısa istisnalar dışında, kaldırıldı ve nihayet, gerçek kademeli vergilendirme resmi olarak 18 Mart 1793'te kabul edildi (Chanel, 2015: 79-80). 1804'ten itibaren dolaylı vergi idaresi tek bir kurum altında merkezileşmeye başladı. Topluca droits reunis adı verilen alkollü içecekler, tuz, tütün, oyun kartları ve toplu taşıma üzerindeki vergiler bir araya getirildi, kabaca General Farms Şirketi altında devrim öncesi merkezileşme yeniden gerçekleştirildi. Diğer vergiler (gümrükler dahil) 1814, 1816 ve 1852 'de bu yapıya dahil edildi. 1830'ların ortasında ve sonundaki Fransa'da, antik rejiminin yeniden yaşadığı görülebilirdi (Pinkney, 1986).

Devrimin ve XIX. yüzyıl boyunca Fransa'da yapılan çok sayıda hükümet değişikliğinin, devletin personelini patrimonyal bir aristokrasiden bürokratik bir meritokrasiye ne ölçüde değiştirdiğine dair devam eden tartışmalar vard1 ${ }^{30}$. 1795-1799 döneminde uzmanlaşma, iş bölümü, hiyerarşi, arşivleme sürecinin kurumsallaşması gibi bürokratik gelişmeler yaşanmıştı. Merkezileşme ve bürokratikleşme en çok hesap kontrollerinde önemli ilerlemeler kaydedilmesini sağlamıştı. Ancak 1799 yılına gelindiğinde bürokratikleşme süreci tam anlamıyla başarılamamıştı (Kiser \& Kane, 2001: 206-207). Hükümet, idare kurumları ve iktidardaki kişiler farklıydı, ancak devrim firtınaları, her ne kadar 1790'larda ve ondan sonraki on yılda olayların yüzeyini çalkalamış olsalar da Fransızların temel yönlerini büyük ölçüde değiştirmemişti (Pinkney, 1986). Kamu hizmetlerine alımlarda düzenli bir sistem geliştirilememişti, miras, satın almalar gibi yöntemler kullanılmış, pratikte ise kayırmacılık yaygın olmuştu. Vergi tahsilatı sürecinin reforme edilmesinde ise devrim pek başarılı olamamıştı. Vergi tahsilatında reform, güç sahipleri ve makam sahipleri tarafindan engellenmişti (Kiser \& Kane, 2001: 206-207).

Merkezileşme başarısızlığının en önemli nedeni, en azından XIX. yüzyılın ortalarına kadar yeterli yerel yolların olmamasıydı. 1830'larda Fransa, 1780'lerde olduğu gibi, tarımsal, kırsal, merkeziyetten uzak, büyük ölçüde köylülerin yaşadığı ve toprak sahipleri aristokrasisinin hakimiyetindeydi. Ancak 1840'larda ufuk açıcı gelişmeler yaşandı. Yolların yapımında bir "devrim" yaşandı, ancak ilk olarak en büyük yolları etkiledi. 1851'de iletişim alanında gelişmeler yaşandı ve telgraf Paris'i Fransa' daki her departmana bağladı ve yeterli

30 XIX. yüzyılda Fransız yönetimi himaye ve liyakat karışımına dayanmaktaydl. Öncelikli olarak eski rejim çalışanlarının çoğunun konumlarını koruması nedeniyle, yönetim personeli devrimden sonra pek değişmemişti. 1830 yllında Fransa'daki personelin yaklaşık \%45'inin kökeni asillere dayanmaktaydı. Ancak bu durum 1840 ’larda değişmeye başladı ve ĕgitim nitelikleri giderek daha önemli hale geldi. Bkz. Kiser \& Kane, 2001. 
Kaya, P.H. (2021), “Âdem-i Merkeziyetçilik-Merkeziyetçilik Tartışmaları Bağlamında Osmanlı Devleti ve Fransa'da Savaşlar, Mali Baskılar, Kurumsal Değişim”, Sosyoekonomi, 29(50), 433-463.

posta hizmeti de yüzyılın ortalarında gelişmeye başladı. Fransız devletinin izleme kapasitesi, nihayetinde dramatik bir şekilde gelişmeye başlamıştı (Pinkney, 1986: 50-60). XX. yüzyıla kadar devlet gücünün merkezileşmesine karşı direniş ve buna eşlik eden "mali engizisyon" korkusu, devletin gelir ihtiyaçlarını karşılamak için tüketim vergilerine güvenmesine yol açarak efektif bir gelir vergisi koyma dürtüsünü zayıflattı. Dolaysız vergi idaresi bu nedenle merkezileşememişti. Ancak 1914 yılında dolaysız vergi idaresinin merkezileşmesi adına önemli bir adım atılarak devletin ilk kez bireyleri doğrudan vergilendirebileceği gelir vergisi gelişti (Morgan \& Prasad, 2009: 1350).

Dönem itibariyle Fransız Devrimi öncesinde hüküm süren, Avusturya ve Rusya ile yıkıcı savaşlar veren III. Selim ve ardından II. Mahmud alınan mağlubiyetler ve azalan gelirlerden sonra köklü değişikliklere gitmeye karar vermişlerdi. Bu doğrultuda 24 Ocak 1839 tarihinde ilan edilen Tanzimat fermanı ile taşra idaresinde önemli değişiklikler olmuştu. Tımar usulü ve mütesellimlik lağvedilerek, muhassıllık sistemi ${ }^{31}$ ile vilayetlere memurlar gönderilmeye başlanmış ve vergileme ile ilgili tüm işlemler bu kişiler aracılığıyla gerçekleştirilmişti. Sonuç olarak "herkesin emlak ve arazi ve hayvanatına ve esnaf ve tüccar kısmının yıllık gelirlerine birer kıymet takdir olunmak suretiyle ve binde hesabiyla... ancema'tin tevzi olunan temettü vergisi" uygulamaya konuldu (Sayın, 1999: 379). 1840 tarihinden itibaren eyaletlere merkeze bağlı muhassılların gönderilmesi ile vali ve sancakbeylerinin salâhiyetleri daraltılmış oluyordu. Muhassıllar, taşralardaki meclislerin de başkanı idi. Ancak iki sene sonra muhassıllık sisteminden istenilen başarıya ulaşılamadığ için kaldırıldı ve tekrar iltizam sistemine dönüş yapıldı. Taşra gelirlerinin toplama işi yeniden mültezimlere verildi ve vali ve sancakbeylerine eski salâhiyetleri tanındı (Ekinci, 2008: 29).

Tanzimat dönemi yönetiminin temel özelliğini merkeziyetçilik ve bürokratikleşme oluşturmakla birlikte uygulamada çeşitli sıkıntılara yol açmıştı (Eryılmaz, 1992: 12). Batılı ülkeler tarzında merkezi ve taşra örgütlenmesi anlayışına geçişin ilk örneğini oluşturan Tanzimat ile devlet sadece vergi toplama, asker besleme ve adalet dağıtma merkezli olmaktan çıkmış, eğitim, sağlık, bayındırlık ve ekonomi işılerini de yürütmeye başlamıştı (Acun, 1999: 158). Bu değişimlerin en önemli aracını da bürokrasi oluşturmuştu. Toplumu yönlendirme aracı olarak bürokrasi yeni kuralların uygulamaya konulmasını gerektirmişti (Ökmen, 2007: 8). Çünkü merkezi yönetimi güçlendirme girişimleri ile merkeziyetçilik artmış ancak, merkezi erk padişahta yoğunlaşmak yerine reformlara öncülük eden bürokratlarda yoğunlaşmıştı (Mardin, 1996: 126).

31 Muhassıl kelimesi Arapça kökenlidir ve "tahsil edici” anlamındadır. Tanzimat Fermanı sonrası 25 Ocak 1840 tarihinde çıkarılan bir nizamnâme ile geçmişten beri şikâyetlere sebep olan ve halkı ve devleti zarara uğratan iltizam sisteminin kaldırllmasına karar verilmiş, bu karar çerçevesinde muhassıllık sistemi getirilerek çeşitli isimlerle alınan vergilerin yerine herkesten geliri oranında tek bir verginin tahsil edilmesi esası benimsenmiştir. Böylece iltizam sisteminde halkla devlet arasında aracılık eden ve devletin gelirlerinin toplanmasında önemli rol oynayan mültezimlerin görevine son verilerek vergileri toplamakla vazifeli ve doğrudan merkeze bă̆ll olan muhassıl-ı emvâl adlı görevliler atanmıştır. Bkz. Özkaya \& Akyıldız, 2006. 
Kaya, P.H. (2021), “Âdem-i Merkeziyetçilik-Merkeziyetçilik Tartışmaları Bağlamında Osmanlı

Devleti ve Fransa'da Savaşlar, Mali Baskılar, Kurumsal Değişim”, Sosyoekonomi, 29(50), 433-463.

\section{Sonuç}

Merkezi bir hükümet bürokrasisinin kurulması ve ülkede gelişmiş kurumların varlığ1 vergilerin toplanması adına modern bir ekonominin temel özelliklerinin oluşturmaktadır. Fransa'da General Farms gibi özel statüdeki bir şirket çatısı altında kişiler sermayelerini bir araya getirebilmişken Osmanlı Devleti'nde bu tarz gelişmiş kurumlarının yokluğu nedeniyle böyle bir koalisyon mümkün olamamıştı.

Fransız mali sistemi ile Osmanlı Devleti’nin mali sistemi pek çok açıdan benzerliklere sahipti. Her ikisi de yüzyıllar boyunca hem doğrudan hem de dolaylı vergi gelirlerinin önemli bir kısmını iltizam sistemi ile topladı. Her iki ülkede de çok çeşitli vergi türleri söz konusuydu ve bazı vergilerden soyluların, din adamlarının, seçkinlerin, bazı resmi kişilerin ve bazı bölgelerin muaf olması sonucu vergi yükünün çoğu orta ve fakir sınıfın sırtına yüklenmişti. Özellikle savaş dönemlerinde merkezi hazinelerinin ihtiyaçları doğrultusunda her iki ülke de olağan vergilerine ek olarak olağanüstü durum vergisi almaya başladı ve bu konulan yeni vergiler zamanla nakit ihtiyacının artmasından dolayı olağan hale dönüştürüldü. Her ikisinde de merkezi hükümet iltizam sistemi içerisinde halktan vergi gelirlerini toplarken yüksek işlem maliyetleri ile karşı karşıya kaldı. Hem padişahlar hem de krallar, bir taraftan vergi gelirleri karşılığında mülkiyet haklarını takas etmek zorunda kalırken diğer taraftan kendi çıkarları doğrultusunda bu mülkiyet haklarını değiştirdiler. Tüm bu yaşananlar hem Fransa'da hem de Osmanlı Devleti'nde mülkiyet hakları üzerindeki belirsizlikleri artırdı. Bununla birlikte, XVII. yüzyılda yaşanan mali krizler sonucu ülkelerde kurumların gelişimi farklı yönde ilerledi. Fransız ve Osmanlı mali sistemlerinde XVII. yüzyılın sonlarında başlayan kurumsal değişimin en önemli nedenleri savaşlar, savaşların maliyeti ve savaş teknolojisindeki gelişmelerdi. Her iki ülkede de bütçe açığının finansmanı, belirsiz mülkiyet haklarına yol açtı ve bu da vergi tahsildarlarını mülkiyet haklarını korumak için yeni kurumlar oluşturmaya sevk etti. Osmanlı Devleti'nde hazineye ek gelir sağlamak adına kademeli reformlar atılarak öncelikle iltizam sisteminden malikâne sistemine sonrasında esham sistemine geçilmişti. Malikâne sisteminde mukataaların sözleşmeleri dolmadan artan nakit ihtiyacını karşılamak adına başka mültezimlere verilmesi, malikâne sahiplerinin önemli bir kısmının İstanbul'da yaşayıp mukataaları gayri resmi olarak başkalarına iltizama vermeleri mülkiyet haklarındaki belirsizliği daha da artırmıştı.

Fransa, özel sektörden kamusal vergi toplamaya ve yerel olarak kontrol edilen yönetimden (âdem-i merkeziyetten) daha merkezi yönetime geçiş için çeşitli girişimlerde bulundu. Fransa'da iltizamcılar, varlıklarını mevcut mali sistemin sürdürülmesinde büyük bir payı olan General Farms şirketi altında birleştirdiler. Osmanlı Devleti'nde ise vakıf sistemi ülkede her alanda faaliyet göstererek mali sistemin önemli bir parçası olmuştu. Özellikle para vakıfları aracılığıyla hem istihdam artmakta hem de tüketici, esnaf ve girişimcinin sermaye ihtiyacı karşılanmaktaydı. Ancak para vakıfları tek bir kişinin tasarrufu ile kurulduğu için kişilere verdiği sermaye miktarı da görece azdı. Bununla beraber bir girişimci para vakıflarının teminat olarak ev gösterilmesini istemesinden dolayı aynı anda farklı para vakıflarından da kredi alamıyordu. Bu durum Osmanlı Devleti'nde girişimcilerin büyük ölçekte sermaye biriktirmelerini ve General Farms gibi bir iltizamcılar 
Kaya, P.H. (2021), “Âdem-i Merkeziyetçilik-Merkeziyetçilik Tartışmaları Bağlamında Osmanlı Devleti ve Fransa'da Savaşlar, Mali Baskılar, Kurumsal Değişim”, Sosyoekonomi, 29(50), 433-463.

koalisyonunun oluşmasını engelleyen bir unsur olarak karşımıza çıkmaktaydı. Osmanlı Devleti'nde vergi tahsildarları böyle bir birleşmeye gitmezken zaman içerisinde hem sayıları hem çıkarları arttı. Ne Fransızların General Farms şirketi ile merkezileşmeye yönelmesi ne de Osmanlı Devleti'nin iltizam ve devamında malikâne sistemi ile âdem-i merkeziyetçilik hamlesi mali krizlerin çözümünde yeterli düzeyde etkili oldu.

Fransa'da antik rejimin bütçe açı̆̆ı krizi, vergi sisteminde reform yapılması çağrılarıyla karşılandı. Fransa'daki reformlar, iletişim, ulaşım ve kayıt tutmanın yetersiz gelişimi nedeniyle genellikle verimliliği artırmadı, bu nedenle kısa ömürlü oldu. Fransız kralları, XVIII. yüzyılda mevcut mali kurumlara Osmanlı Devleti meslektaşlarından daha güçlü bir şekilde bağlıydı. Nihayetinde, mevcut mali kurumlarla olan bağları, Fransa'da ancak yerleşik çıkarları silip süpüren kapsamlı reformları gerçekleştirmelerine neden oldu ve Fransız Devrimi yaşandı. Devrim ve merkezileşme arasındaki ilişki karmaşıktır. Devrimin Fransa'da merkezileşme üzerinde önemli etkileri oldu, ancak bu yönde bazı reformlar devrimden önce gerçekleşti ve vergi idaresinin bazı türleri bir yüzyıldan fazla bir süre merkezileşemedi. Buradan iki sonuç çıkarabiliriz; birincisi, devrim merkezileşme için ne gerekli ne de yeterli bir koşuldu; ikincisi ise merkezileşme farklı yönetim düzeylerinde ve devletin farklı bölümlerinde farklı şekillerde gerçekleşmekteydi. Fransız Devrimin belki de en önemli etkisi, eyaletlerde dolaylı vergilerin iltizam sistemi ile toplanmasının devrimle sona ermesiydi. Dolaysız vergilerin merkezileştirilmesi ise ancak devrimden bir yüzyıl sonra gerçekleştirilebilmiş ve bu süreçte dolaysız vergiler âdem-i merkeziyetçi bir yapıda toplanmaya devam etmişti.

Sonuç olarak şunu söyleyebiliriz ki, dolaylı vergilerin tahsiline yönelik General Farms Şirketi ile böyle bir kira sözleşmesinin kabul edilmesi, XVII. yüzyılın son dönemlerinde ve XVIII. yüzyıl boyunca Kral'ın temsilcilerini kontrol ve takip etmede karşılaştığı zorluklardan ve vergi gelirlerindeki eksikliklere karşı riskleri göze alamamasından kaynaklanmaktaydı. Ancak bu durum Fransa'da iltizamciların General Farms Şirketi altında sermayelerini birleştirerek Krala karşı kısıtlamalar getirmeyi başarabilmelerine ve kurumsal yapılarını da bu doğrultuda değiştirmelerine olanak sağlamıştı. Osmanlı Devleti'nde ise iltizamcılar yüksek işlem maliyetlerini Fransa'dakiler gibi karşılayamayıp böyle bir birleşmeye gidemedi. Osmanlı Devleti’nde, Fransa'daki gibi bir devrim gerçekleşmemiş tam tersine Osmanlı padişahları, XIX. yüzyıla kadar maliye sisteminde kademeli reformlar gerçekleştirerek iltizam sisteminden malikâne sistemine ve esham uygulamalarına geçerek mali bunalımlarına çözüm aramıştı. Ancak XVIII. yüzyılın sonlarında yerelde ayânların güçlenmesi, vergi gelirlerinin azalması, halkın aşırı yıpratılması sonucu mali alanda yenileşmeye yönelik adımlar atılmış ve Tanzimat reformu ile iltizam sisteminin kaldırılıp vergi idaresinin merkezileştirilmesine karar verilmişti. Ancak taşrada kurulan Muhassıllık teşkilatları aracılığıyla vergi gelirlerinin toplanmasında bir artış sağlanamadığ 1 için iki yıl sonra 1842 yılında yeniden iltizam sistemine bazı değişikliklerle geri dönülmüştü. Osmanlı Devleti’nde merkeziyetçi ve âdem-i merkeziyetçi yapı yüzyıllar içerisinde hep iç içe olmuştu. 
Kaya, P.H. (2021), “Âdem-i Merkeziyetçilik-Merkeziyetçilik Tartışmaları Bağlamında Osmanlı

Devleti ve Fransa'da Savaşlar, Mali Baskılar, Kurumsal Değişim”, Sosyoekonomi, 29(50), 433-463.

\section{Kaynaklar}

Acemoğlu, D. \& J.A. Robinson (2014), Ulusların Düşüşü: Güç, Zenginlik ve Yoksulluğun Kökenleri, çev. F.R. Velioğlu, İstanbul: Doğan Kitap.

Acemoğlu, D. et al. (2002), "Reversal of Fortune: Geography and Institutions in the Making of the Modern World Income Distribution”, The Quarterly Journal of Economics, 117(4), 1231-1294.

Acun, F. (1999), “Osmanlı'dan Türkiye Cumhuriyeti’ne: Değişme ve Süreklilik”, H.Ü. Edebiyat Fakültesi Dergisi, Osmanlı Devletinin Kuruluşunun 700. Yı1ı Özel Sayıs1, 155-167.

Akdağ, M. (1974), “Osmanlı Tarihinde Ayânlık Düzeni Devri 1730-1839”, Tarih Araştırmaları Dergisi, 8-12 (14-23), 51-61.

Akgündüz, A. (1990), Osmanlı Kanunnameleri ve Hukuki Tahlilleri/ Osmanlı Hukukuna Giriş ve Fatih Devri Kanunnameleri, Fey Vakfı Yayıları.

Balla, E. \& N.D. Johnson (2009), "Fiscal Crisis and Institutional Change in the Ottoman Empire and France", The Journal of Economic History, 69(3), 809-45.

Barkan, Ö.L. (1955), “1070-71 (1660-61) Tarihli Osmanlı Bütçesi ve Bir Mukayese”, İ. Ü. Íktisat Fakültesi Mecmuası, 17(1-4), 304-347.

Barkan, Ö.L. (1955), “1079-80 (1669-70) Mali yılına Ait Bir Osmanlı Bütçesi ve Ekleri”, İ.̈̈. İktisat Fakültesi Mecmuası, 17(1-4), 1955, 225-303.

Barkan, Ö.L. (1980), Timar, Türkiye'de Toprak Meseleleri, Toplu Eserler -1-, Cilt: 2, Gözlem Yayınlar1.

Batmaz, E. (1996), “İltizam Sisteminin XVIII. Yüzyıldaki Boyutları”, Tarih Araştırmaları Dergisi, $18,39-50$.

Bloch, H. (1940), "The Evolution of French Taxation-An Historical Sketch",. The Bulletin of the National Tax Association, 25(9), 266-273.

Bossenga, G. (2003), The Politics of Privileges: Old Regime and Revolution in Lille, Cambridge: Cambridge University Press.

Brissaud, J. (1915), A History of French Public Law, Boston: Little Brown.

Buluş, A. (2010), "Vergi Toplamanın Özerkleștirilmesinin Vergi Toplamanın Etkinliğine Katkısı: İltizam Sistemi ile Bir Mukayese”, Kocaeli Üniversitesi Sosyal Bilimler Enstitüsü Dergisi, 19(1), 81-120.

Cezar, Y. (1986), Osmanlı Maliyesinde Bunalım ve Değişim Dönemi, İstanbul: Alan Yayıncılık.

Chanel, G. (2015), "Taxation as a Cause of the French Revolution: Setting the Record Straight", Studia Historica Gedanensia, VI. 65-81.

Çizakça, M. (1999a), “Osmanlı İmparatorluğu’nda İç Borçlanmanın Evrimi (XV. Yüzyıldan XIX.

Yüzyıla)”, içinde: Osmanlı Ansiklopedisi, C.3, Ankara: Yeni Türkiye Yayınları, 226-233.

Çizakça, M. (1999b), İslam Dünyası ve Batı'da İş Ortaklıklarının Tarihi, İstanbul: Tarih Vakfı Yurt Yayınlar1.

Doyle, W. (1996), Venality: The Sale of Offices in Eighteenth-Century France, Oxford: Clarendon Press.

Döndüren H. (2008), “Osmanlı Tarihinde Bazı Faizsiz Kredi Uygulamaları ve Modern Türkiye’de Faizsiz Bankacılık Tecrübesi”, U.Ü. Illâhiyat Fakültesi Dergisi, 17(1), 1-24. 
Kaya, P.H. (2021), “Âdem-i Merkeziyetçilik-Merkeziyetçilik Tartışmaları Bağlamında Osmanlı Devleti ve Fransa'da Savaşlar, Mali Baskılar, Kurumsal Değişim”, Sosyoekonomi, 29(50), 433-463.

Ekinci, E.B. (2008), “Osmanlı İdaresinde Adem-i Merkeziyet ve İmtiyazlı Eyâletler”, Türk Hukuk Tarihi Araştırmalarl, 6, 7-84.

Emecen, F. (1988), “Ağnam Resmi”, TDV İslam Ansiklopedisi, C.1, 478-479.

Emecen, F. (1993), “Cebelü”, TDV Íslam Ansiklopedisi, C.7, 188-189.

Eryılmaz, B. (1992), Tanzimat ve Yönetimde Modernleşme, İstanbul: İşaret Yayını.

Faroqhi, S. (1994), Osmanlı'da Kentler ve Kentliler, İstanbul: Tarih Vakfi Yurt Yayını.

Genç, M. (1995), "Esham”, TDV İslâm Ansiklopedisi, C.11, 376-380

Genç, M. (2000), “İltizam”, TDV Íslam Ansiklopedisi, C.22, 154-158.

Genç, M. (2006), "Mukataa”, TDV İslam Ansiklopedisi, C. 31, 129-132.

Genç, M. (2009), Osmanlı İmparatorluğunda Devlet ve Ekonomi, İstanbul: Ötüken Neşriyat.

Hazan, E. (2015), Fransız Devriminin Kısa Tarihi, İstanbul: Say Yayınları.

İnalcık, H. (1993), "Cizye”, TDV İslam Ansiklopedisi, C. 8, 45-47.

İnalcık, H. (2000), Osmanlı İmparatorluğu’nun Ekonomik ve Sosyal Tarihi, Cilt 1: 1300-1600, (ed:

H. İnalcık \& D. Quatert), Çev. Halil Berktay, İstanbul: Eren Yayıncılık.

Johnson, N.D. (2006), "The Cost of Credibility: The Company of General Farms and Fiscal

Stagnation in Eighteenth Century France", Essays in Business and Economic History, 24, 16-28.

Katıranc1, Ü. (2015), Iltizam ve Malikane Sistemi, <https://www.academia.edu/7925931/\%C4\%B0ltizam_ve_Malikane_Sistemi>, 12.12.2020.

Kaya, P.H. (2017), 18. Yüzyılda Konya'nın Mali Yapısı ve Merkez Maliyesi ile İlişkisi, Ankara: Nobel Yayınevi.

Kazıcı, Z. (2003), Osmanlı'da Vergi Sistemi, Bilge Yayıncılık.

Kiser, E. \& J. Kane (2001), "Revolution and State Structure: The Bureaucratization of Tax Administration in Early Modern England and France", American Journal of Sociology, 107(1), 183-223.

Kumaş, M.S. (2006), "Bir Finansman Yöntemi Olarak İş Ortaklığı Uygulaması (MudârabeCommenda Karşılaştırması)", U.Ü. İlâhiyat Fakültesi Dergisi, 15(1), 369-383.

Kuran, T. (2005), "The Absence of the Corporation in Islamic Law: Origins and Persistence", The American Journal of Comparative Law, 53(4), 785-834.

Kuran, T. (2012), Yollar Ayrllırken Ortadoğu'nun Geri Kalma Sürecinde İslam Hukukunun Rolü, (çev. N. Elhüseyni), İstanbul: Yapı Kredi Yayınları.

Kwass, M. (2000), Privilege and the Politics of Taxation in Eighteenth-Century France: Liberté, Egalité, Fiscalité, Cambridge: Cambridge University Press.

Mardin, Ş. (1996), Yeni Osmanlı Düşüncesinin Doğuşu, İstanbul: İletişim Yayınları.

Markoff, J. (1996), The Abolition of Feudalism, University Park: Pennsylvania State University Press.

Matthews, G. (1958), The Royal General Farms in Eighteenth-Century France, New York: Columbia University Press.

Morgan, K. \& M. Prasad (2009), "The Origins of Tax Systems: A French-American Comparison”, American Journal of Sociology, 114(5), 1350-1394. 
Kaya, P.H. (2021), “Âdem-i Merkeziyetçilik-Merkeziyetçilik Tartışmaları Bağlamında Osmanlı Devleti ve Fransa'da Savaşlar, Mali Baskılar, Kurumsal Değişim”, Sosyoekonomi, 29(50), 433-463.

Norberg, K. (1994), Fiscal Crises, Liberty and Representative Government, 1450-1789, Stanford: Stanford University Press. 226-252.

Öğün, T. (2006), "Müsâdere”, TDV İslam Ansiklopedisi, C. 12, 67-68.

Ökmen, M. \& A. Y1lmaz (2015), “Klasik Dönemden Tanzimat'a Osmanlı Kenti ve Yerel Yönetimler”, Dumlupınar Üniversitesi Sosyal Bilimler Dergisi, 23, 91-112.

Ökmen, M. (2007), “Osmanlı'dan Cumhuriyet'e Türkiye'de Merkeziyetçilik- Âdem-i

Merkeziyetçilik Pratiği Üzerine Notlar”, Akademik Araştırmalar Dergisi, 9(10), 1-25.

Öner, E. (2005), Osmanlı Imparatorluğu ve Cumhuriyet Döneminde Mali İdare, Ankara: T.C.

Maliye Bakanlığı Araştırma Planlama ve Koordinasyon Kurulu Başkanlığı Yayınları.

Özdeğer, M. (2000), “Osmanlı Devlet Teşkilâtında Âyanın Mali ve İdari Yönetime Müdahale Devri”, İ.Ü. İktisat Fakültesi Mecmuası, 50(1-4), 69-132.

Özkaya, Y. \& A. Akyıldız (2006), “Muhassıl”, TDV Íslam Ansiklopedisi, C. 31, 18-20.

Özvar, E. (2003), Osmanlı Maliyesinde Malikane Uygulaması, İstanbul: Kitabevi Yayınları.

Pamuk, Ş. (2010), Osmanl-Türkiye İktisadi Tarihi 1500-1914; İstanbul: İletişim Yayınları.

Pamuk, Ş. (2013), Osmanlı Ekonomisi ve Kurumları, İstanbul: İş Bankası Yayınları.

Pamuk, Ş. (2014), "Fiscal Centralisation and the Rise of the Modern State in the Ottoman Empire", The Medieval History Journal, April, 1-27.

Peter, M.J. (1988), The Peasantry in the French Revolution, Cambridge: Cambridge University Press.

Pinkney, D. (1986), Decisive Years in France, 1840-1847, Princeton N.J.:Princeton University Press.

Potter, M.R. (2003), "War Finance and Absolutist State Development in Early Modern Europe: An Examination of French Venality in the Seventeeth Century", Journal of Early Modern History, 7(1), 120-147.

Riley, J.C. (1987), "French Finances 1727-1768”, The Journal of Modern History, 59(2), 209-243.

Rodrik, D. et al. (2004), "Institutions Rule: the Primacy of Institutions over Geography and Integration in Economic Development", Journal of Economic Growth, 9(2), 131-165.

Sahillioğlu, H. (1969), “Savaş Yılı Buhranları”, İ.Ü. İktisat Fakültesi Mecmuası, 27(1-2), 75-111.

Salzmann, A. (2004), Tocqueville in The Ottoman Empire Rival Paths to the Modern State, The Ottoman Empire and, its Heritage, Politics, Society and Economy, (eds. S. Faroqhi \& H. Inalc1k), Boston: Brill Leiden.

Sargent, A.J. (2004), The Economic Policy of Colbert, $<$ http://socserv2.socsci.mcmaster.ca/econ/ugcm/3113/sargent/EconomicPolicyColbert.pdf $>$, 12.12.2020.

Sargent, T.J. \& F.R. Velde (1995), "Macroeconomic Features of the French Revolution", Journal of Political Economy, 103(3), 474-518.

Sayın, A.V. (1999), Tekâlif Kavaidi (Osmanlı Vergi Sistemi), (çev. F.H. Özkan), Ankara: T.C. Maliye Bakanlığı Araştırma, Planlama ve Koordinasyon Kurulu Başkanlığı Yayınları.

Skocpol, T. (1979), States and Social Revolutions, Cambridge: Cambridge University.

Sofrac1, İ.E. \& M. Ergenoğlu, (2016), "Devletin Mültezimlerle Uzlaşma Yöntemleri: XVIII. Yüzyıl Adana Sancağı Örneği”, M.K.Ü. Sosyal Bilimler Enstitüsü Dergisi, 13(35), 384-401.

Tabakoğlu, A. (1985a), Gerileme Dönemine Girerken Osmanlı Maliyesi, İstanbul: Dergâh Yayınları. 
Tabakoğlu, A. (1985b), “XVII ve XVIII. Yüzy1l Osmanlı Bütçeleri”, İ.̈̈. İktisat Fakültesi Mecmuast, 41(1-4), 389-414.

Tabakoğlu, A. (2014), Türkiye İktisat Tarihi, İstanbul: Dergâh Yayınları.

Tilly, C. (1975), The Formation of National States in Western Europe, Princeton, N.J: Princeton University.

Udovitch, A. (1962), “At The Origins of Western Commenda: Islam, Israel, Byzantine?”, Speculum, 37(2), 198-207.

Velde, F.R. (2006), French Public Finance Between 1683 and 1726, <http://www.helsinki.fi/iehc2006/papers3/Velde.pdf>. 12.12.2020.

Weber, M. (2012), Ekonomi ve Toplum, 2 Cilt, Yarın Yayınları.

Weiker, W.F. (1968), “The Ottoman bureaucracy: Modernization and reform”, Administrative Science Quarterly, 13(3), 251-270.

White, E.N. (2001), "France's slow transition from privatized to government-administered tax collection: Tax farming in the eighteenth century", Working Paper, No. 2001-16, Rutgers University, Department of Economics, New Brunswick, NJ. 
Kaya, P.H. (2021), “Âdem-i Merkeziyetçilik-Merkeziyetçilik Tartışmaları Bağlamında Osmanlı Devleti ve Fransa'da Savaşlar, Mali Baskılar, Kurumsal Değişim”, Sosyoekonomi, 29(50), 433-463. 